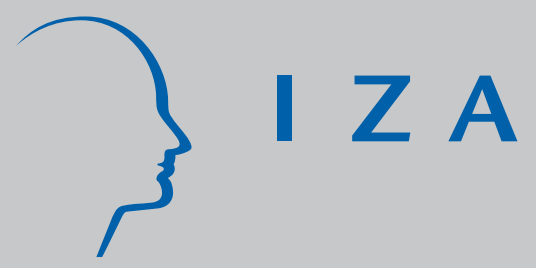

IZA DP No. 2294

ICT Adoption and Productivity in Developing Countries:

New Firm Level Evidence from Brazil and India

Rakesh Basant

Simon Commander

Rupert Harrison

Naercio Menezes-Filho

September 2006 


\title{
ICT Adoption and Productivity in Developing Countries: New Firm Level Evidence from Brazil and India
}

\author{
Rakesh Basant \\ Indian Institute of Management Ahmedabad
}

Simon Commander

London Business School and IZA Bonn

Rupert Harrison

Institute for Fiscal Studies, London

Naercio Menezes-Filho

Universidade de São Paulo

\section{Discussion Paper No. 2294 \\ September 2006}

\author{
IZA \\ P.O. Box 7240 \\ 53072 Bonn \\ Germany \\ Phone: +49-228-3894-0 \\ Fax: +49-228-3894-180 \\ Email: iza@iza.org
}

\begin{abstract}
Any opinions expressed here are those of the author(s) and not those of the institute. Research disseminated by IZA may include views on policy, but the institute itself takes no institutional policy positions.

The Institute for the Study of Labor (IZA) in Bonn is a local and virtual international research center and a place of communication between science, politics and business. IZA is an independent nonprofit company supported by Deutsche Post World Net. The center is associated with the University of Bonn and offers a stimulating research environment through its research networks, research support, and visitors and doctoral programs. IZA engages in (i) original and internationally competitive research in all fields of labor economics, (ii) development of policy concepts, and (iii) dissemination of research results and concepts to the interested public.
\end{abstract}

IZA Discussion Papers often represent preliminary work and are circulated to encourage discussion. Citation of such a paper should account for its provisional character. A revised version may be available directly from the author. 
IZA Discussion Paper No. 2294

September 2006

\section{ABSTRACT \\ ICT Adoption and Productivity in Developing Countries: New Firm Level Evidence from Brazil and India*}

This paper uses a unique new data set on nearly a thousand manufacturing firms in Brazil and India to investigate the determinants of ICT adoption and its impact on performance in both countries. The descriptive evidence shows that Brazilian firms on average use ICT more intensively than their Indian counterparts but changes over time have been rather similar in both places. Within countries ICT intensity is strongly related to size, ownership structure, share of administrative workers and education. The econometric evidence documents a strong relationship between ICT capital and productivity in both countries, even after controlling for several other factors, including firm-specific fixed-effects. The rate of return of ICT investment seems to be much larger than usually found in more developed countries. Specific types of organisational changes matter for the return of ICT, but only for high adopters. Firms report several constraints to ICT investment in both countries and power disruption seems to significantly depress adoption and returns to ICT expenditures in India. This may be indicative of the impact of a cluster of poor institutions and/or infrastructure on performance.

JEL Classification: J2, E20, L20, L60, O33

Keywords: ICT, productivity

Corresponding author:

Simon Commander

London Business School

Sussex Place

Regent's Park

London NW1 4SA

United Kingdom

E-mail: scommander@london.edu

\footnotetext{
* We thank Sunila Benjamin and her colleagues at AC Nielsen, Bangalore and Ricardo Guedes and his colleagues at Sensus, Belo Horizonte for the data collection. Our research was generously supported by UK DfID. We thank Randolph Bruno, Axel Heitmueller and Rachel Griffith for discussions and help at various points.
} 


\section{Introduction}

There is now a large - and growing - literature on the impact of ICT and associated changes in working practices on productivity. It is now widely accepted that ICT has had important and positive implications for both productivity and output growth. Yet most of that literature is concerned with the developed economies. The extent of adoption and the consequences for firm and economy-wide performance in developing countries remains largely terra incognita. Yet, as the price of computing has fallen dramatically and the availability of ICT technology has diffused, we would expect adoption rates in developing countries to have increased. To what extent and with what effectiveness this has happened remains, however, much of a puzzle.

This paper is an attempt to begin to redress this imbalance in focus. It does so by using a unique dataset that we have collected containing nearly a thousand firm-level observations for several points in time for two major developing countries, Brazil and India. The data cover six three-digit manufacturing branches located in multiple regions of these two large countries. Using this rich dataset, the picture that emerges is indeed one of considerable heterogeneity in both adoption and performance. Not only do we find that there are significant differences in the timing of adoption and the resulting patterns of ICT usage across the two countries, but that there are also differences within the countries themselves. We also find strong and robust evidence of large effects of ICT usage on performance. These effects cut across sectors and countries and seem to be related to organisational changes and to regional constraints.

The paper is organised in the following way. Section 2 provides an overview of the recent literature from both developed and developing country contexts. Section 3 describes the properties of the new dataset that we have collected and analysed. Section 4 then turns to look at the determinants of adoption rates in the two developing countries. Section 5 is concerned with the impact of ICT investment and other co-investments on the performance of firms in our sample. Section 6 examines the constraints on ICT adoption operating at the level of a region, as well as the consequences for the returns to ICT investment. Section 7 concludes. 


\section{Literature review}

In the context of the developed countries, there is now a wide consensus in the literature that ICT can deliver significant and persistent improvements in performance for technology adopters ${ }^{2}$. Much of the existing research has been based on growth accounting, mostly using US data ${ }^{3}$. This body of work has generally found that ICT has contributed in a significant and growing way to increases in productivity. These increases reflect not only the sharp decline in the relative price of computing power and memory, but also rising output shares. While most of the research has focussed on manufacturing, there has been some recent effort to look at the impact in services and, again, evidence from the USA suggests that there has been a strong contribution from ICT to labour productivity growth in this sector ${ }^{4}$.

While ICT has itself undergone major changes over time - such as the advent of the networked computer and the growth of the Internet and associated bandwidth - the impact on an adopting firm's performance could be expected through a number of channels. These include faster processing of information and products, the facilitation of changes in business practices and improved management and internal organisation leading to better performance. Indeed, much of the recent research in this area has emphasised less the adoption decision per se than what adoption facilitates. In particular, ICT is widely viewed as enabling changes in business and other processes that in turn can generate improvements in performance. The fact that estimates of the contribution of ICT to output and productivity actually vary widely across countries and sectors, suggests that co-investments and associated changes in process are likely to matter in explaining such differences.

To understand quite how important these factors are, there has been an increasing emphasis on use of firm level evidence, including case studies. Research has stressed the possible complementarity between computer investment and other forms of allied investment, such as in organisational change ${ }^{5}$. Examples of complementary investments could involve the use of new business processes, teamwork, decentralisation, changes in monitoring and hierarchies. Such organisational complements - leading to improvements in intangibles, such as new or better quality goods and improved service speed - have been argued to be important in explaining why particular firms have reaped

\footnotetext{
2 There are exceptions, see, for example, Gordon (2000).

${ }^{3}$ See, inter alia, Oliner and Sichel (1999) and Jorgenson (200?).

${ }^{4}$ For example, see Bosworth and Triplett (2004)

${ }^{5}$ See, inter alia, Bresnahan et al (1999, 2002); Brynjolfsson (2002), Hall and Lynch (2001); Ichniowski et al (1997).
} 
significant productivity benefits and others did not ${ }^{6}$. In short, a wide body of findings, some multi-sector, others focussing on a more narrowly defined industry, have now documented the way in which ICT investment can not only directly affect production processes but also permit other productivity enhancing changes, such as customisation, thereby modifying the overall business strategy of the ICT adopting firm ${ }^{7}$. Indeed, it has also been argued that incomplete implementation of complementary organisational changes can lead firms to be less productive than those that had not implemented any reforms ${ }^{8}$. Further, implementation of such changes could themselves impose substantial learning and adjustment costs. This argument, for example, has been used to explain differences in returns to ICT across countries?.

Attention has also begun to be paid to the role of managerial factors in explaining productivity differences. Survey evidence has been used to compare manufacturing firms in the USA and Europe in terms of their management practices ${ }^{10}$. Measures of management practices were found to be positively correlated with a range of performance indicators and there was a systematic difference between US and European firms in favour of the former. In terms of the possible link from ICT to productivity, Bloom, Sadun and van Reenen (2006) find that for firms operating in the UK the productivity of ICT capital has been significantly higher in US owned establishments than in other firms.

Turning to the developing countries, the evidence to date is much scantier. What is clear is that there is large variation in ICT adoption across and within countries and sectors ${ }^{11}$. This variation can be traced to a variety of factors including differences in pricing and government policy. Shifts in policy preferences - such as privatisation, lowering of trade barriers and de-regulation - have tended to raise investment in communications sectors and to improve access to ICT technology, particularly in middleincome countries, such as Brazil. Even so, firm level surveys point to significant constraints on adoption, including those of an institutional nature - such as business environmental constraints - as well as constraints originating from the labour market, most notably, relative skill shortages. It also seems that inadequate telecommunications services remain a major problem. Despite these limitations, the small body of available

\footnotetext{
${ }^{6}$ A summary of this argument can be found in Brnjolfsson and Hitt (2000).

${ }^{7}$ Bartel et al (2005) use plant-level data on the valve manufacturing industry to make these points.

${ }^{8}$ Bresnahan et al (1997).

${ }^{9}$ See Basu et al (2003).

${ }^{10}$ Bloom and van Reenen (2005).

11 See World Bank (2005) and World Economic Forum (2005) for cross country indicators.
} 
evidence suggests that ICT adoption has accelerated over the past five years and that ICT may exert a positive impact on some adopters' performance. For example, a recent World Bank study reports correlations between a simple measure of ICT use and a number of performance indicators, including growth in sales, employment and reinvestment suggesting that there is some evidence of ICT use being associated with enhanced performance ${ }^{12}$. The lack of more robust econometric evidence is a gap that this paper tries to bridge.

\section{Data description and country context}

Our dataset consists of a unique firm level survey of nearly one thousand firms in two major developing countries, Brazil and India. The survey was implemented in both countries between April-May, 2005 through a series of face-to-face interviews. The survey was designed to give detailed responses to a set of questions relating to ICT adoption and its timing, as well as changes to management and organisational features associated with adoption. In addition, changes to the skill and educational structure of employment, firm level constraints to ICT adoption as well as variables capturing key characteristics of the firm in terms of size and performance and the competitive environment were collected.

For most questions, data was collected for either two or three points in time, namely 2003, 2002 and 2001. In each country a target of 500 firms in six 3-digit manufacturing branches - auto-components, soaps and detergents, electrical components, machine tools, wearing apparels and plastic products - was selected. Stratification was by industry, region and size (employment) with quota sampling. In India, firms were sampled in nine states. In Brazil, firms were sampled in seven regions. Appendix Table 1 gives the distribution of the sample over region and branch and in Brazil, a substantial share of firms was located in two states, Sao Paolo and Minas Gerais, which accounted for over $46 \%$ of total firms surveyed. In India, the distribution was less skewed in terms of location. In terms of response rates, in Brazil the ratio of refusals to responses was 3.4 while in India it was 4.5. Appendix 1 provides more information about the sampling strategy.

Table 1 provides some basic descriptive statistics for the sample for each country broken down for mean and median values of size (employment), sales, materials and wage shares and capital intensity, as well the mean rate of growth in sales and

\footnotetext{
12 World Bank (2006), see Chapter 4 in particular.
} 
employment over the period 2001-2003. There is a good deal of variation in all variables. With respect to employment size, however, the median values are actually very similar across countries, as is the ranking by branch. In both places, employment in autocomponents tends to be significantly larger than in other branches. Average employment growth has been quite similar in both countries, although median growth in India was double that in Brazil. In terms of shares, the major difference between the countries is with respect to labour. In India the mean and median wage shares were only $30-40 \%$ of those in Brazil. Capital intensity was also higher in Brazil but by a far smaller margin.

The six branches of manufacturing that have been sampled were picked not only because they provide significant variation in their production processes - and hence in their likely adoption of ICT - but also because they comprise a significant component of output and employment in manufacturing in both countries. Appendix Table 2 provides a breakdown by branch of the respective shares in employment and value added, as well as growth rates in employment and value added over 1998-2003. The level of the average wage and its change is also reported. In India, it can be observed that these six branches account for nearly $17 \%$ of total manufacturing employment and over $20 \%$ of value added. In Brazil these shares were around 30\% and 32\% respectively. In terms of growth rates in the period from 1998-2003, there are major differences for both employment and value added within and across countries. In India three out of the six branches actually saw declines in employment, while this was only true for electronics in Brazil. Generally, Brazilian employment growth was far stronger over this period than in India. Turning to value added, the story is reversed. In all branches growth in net value added was negative in Brazil, while in India growth averaged over 6.7\%. Growth in labour productivity was positive in all Indian branches, except wearing apparels and averaged \% over the six branches. In Brazil, the picture was more varied, electronics and plastic products saw declines of over 12\%, wearing apparel grew by under $3 \%$ and the others grew in double digits. The wage data also show substantial differences across branches. In India wages in the apparels sector are less than half those in plastics, machine tools or electronics and this pattern is similar in Brazil. There are, however, clearly different rankings and relativities across countries, with auto components and soaps and detergents reporting the highest mean wages in Brazil. There, the ratio of the highest/lowest wage sector was 2.8 as against 2.2 in India. Nominal growth rates of wages show similarly high variation across branches and countries. 
Turning to the broader policy and performance indicators for these two countries over the reference period, there have been significant differences. In India, GDP growth exceeded 6\% over the period, while in Brazil average growth was around 2\%. While this decreased the income gap between the two countries, by 2004 Indian per capita income was only around $13 \%$ of Brazil's, with notably lower literacy, schooling enrolment and other social indicators as well

In terms of ICT indicators, Appendix Table 3 shows major disparities in almost all indicators whether relating to access, quality, efficiency or expenditure. ICT expenditure as a share of GDP was $6.7 \%$ in 2004 in Brazil as against $3.7 \%$ in India. Access to communications was vastly lower in India than in Brazil, whether for fixed line, mobile or Internet and broadband coverage. In terms of ownership and market structure, in Brazil private ownership of telecoms runs alongside competition in provision. In India, by 2004 ownership remain mixed with limited competition, except for internet service providers. ${ }^{13}$ Quite clearly, by these indicators, Brazil remains well ahead of India in terms of overall ICT adoption and investment.

In terms of policy, both countries have seen clear changes over our reference period, particularly in India. Telecommunications have been liberalised, with significant entry of new providers particularly for mobile services and internet service providers in India. With respect to the trade regime, in India, unweighted tariff rates for the six branches fell on average by over 60\% between 1999 and 2005. At the start of the period the average tariff rate was $33.5 \%$, falling to $15 \%$ by 2005 , except in electronics where it was only $1.9 \%$. In Brazil, we only have comparable tariff data for 1998, but the tariff structure has remained basically unaltered since then as most trade liberalization occurred between 1990 and 1995. By 1998, Brazilian tariffs were mostly close to the Indian rates that existed in 2005 and hence were substantially lower than the Indian tariff rates at the start of the period, with the exception of auto-components that received protection of $46 \%$. In the case of labour legislation, in neither country was there significant change over our reference period.

\section{Correlates of adoption}

There is a large literature that is concerned with diffusion of new technology, including ICT. Much of this literature tries to account for the S-curve shape for adoption over

\footnotetext{
${ }^{13}$ World Bank (2006)
} 
time $^{14}$. In what follows our emphasis is less on a detailed look at the diffusion process per se than on the characteristics of firms adopting particular ICT forms and usages in Brazil and India, mainly at one point in time. For the analysis that follows, our leading adoption indicator is constructed from responses to a question regarding the degree of ICT use in a given firm. These ranged from IT not being used at all to all processes being automated and integrated into a central system ${ }^{15}$. Each response was scored for each firm and responses were given for two points in time, 2001 and 2003.

Figure 1 plots the distribution of responses for both years using the 1-5 scale that was applied (the thin bars are for 2001 and the thicker ones are for 2003). Several things stand out. First, the share of Indian firms with little or no adoption (scores of 1 or 2) is higher than in Brazil in both years. In 2001 over 60\% of Indian firms were using ICT in a minimal way, as against $45 \%$ in Brazil. Second, there has been a rapid increase in the share of firms using ICT in both countries. The share of firms with minimal use had declined substantially by 2003 while the gap between Brazil and India had remained roughly constant. Third, it is still the case that by 2003 a far smaller share of Indian firms had the highest adoption scores (4 or 5) than in Brazil. At the top end of the distribution (5) nearly $30 \%$ of Brazilian firms had automated almost all processes with ICT integrated into a central system, as against only $10 \%$ of the Indian sample. The picture that emerges is thus one of significant difference across countries.

Figures 2 and 3 go on to provide adoption curves for PCs and servers at the time of first introduction in both countries. By 2003 98\% of firms in both countries had adopted PCs, while $90 \%$ of Brazilian firms had adopted servers at that time as against only $63 \%$ of Indian firms. The plotted densities show that there is relatively little difference across the two countries with respect to the timing of adoption. The peaks of the kernel densities are both around 1997 for PCs and around 1998 for servers. The fact that the Indian distribution is not shifted to the right suggests that it is not lagging on the extensive margin. For servers, it suggests that there is a longer tail of late adopters in India than in Brazil.

Tables 2 and 3 provide some further descriptive statistics for a set of indicators of ICT adoption for both the level in 2003 and the change over 2001-2003. Mean and

\footnotetext{
${ }^{14}$ For a survey, see Geroski (2000)

15 The possible responses and their scores were: IT is not used at all=1; IT is used only for some office along with accessing the Internet, e mailing $=2$; IT is used for some advanced applications. Most processes are automated but there is no integration into a central system $=3$; Most processes are automated and some of them are integrated into a central system $=4$; Almost all processes are automated and integrated into a central system $=5$
} 
median scores and standard deviations for a usage index are reported. This index was put together from a question regarding the intensity of use for ICT for four functions: accounting services, inventory management, marketing and product design and the production process ${ }^{16}$. In addition, the table reports measures of ICT capital (normalised by either sales or employees) and shares of non-production workers using either PCs or ICT controlled machinery.

For the levels, both the summary measures and hardware usage are always higher for Brazil, but so is their standard deviation. In terms of workforce use, there are particularly sharp differences, since on average nearly $70 \%$ of non-production workers used a PC in Brazil in 2003 as against 54\% in India, while for the proportion of production workers using ICT-controlled machinery the share was around $23 \%$ in Brazil against $15 \%$ in India. In terms of the changes, the differences are less marked. For usage and non-production workers using PCs, the average rate of increase was larger in India and for most of the other indicators the difference was rather small.

Table 4 provides multivariate examination of the correlates of ICT adoption at the firm level in 2003 for six different measures of ICT intensity: Column 1 is the summary index of ICT adoption; Column 2 is our summary index of ICT usage; Column 3 is the share of non-production workers using PCs; Column 4 is the share of production workers using ICT controlled machinery; Column 5 is the logarithm of ICT per worker and the last - Column 6 - is the logarithm of ICT per unit of sales. In the case of the two summary indicators (Columns 1 and 2) estimation is by Ordered Probit, while all other columns use OLS. All regressions reported in Table 4 include industry and region/state dummies.

The measures of adoption are related to a set of variables capturing the size of the firm, its age and ownership type, the share of employees belonging to a union and a set of education and occupation shares. In the case of size, the omitted category is 1-29 employees; for occupation shares the omitted category is production workers; for education shares the omitted category is less than upper secondary (US) for both production and administrative \& clerical workers and for age the omitted category is more than 20 years old.

The results are broadly plausible while also bringing out some interesting differences across countries. In both countries, the size of the firm is generally positively and significantly associated with the indices of adoption and usage, as well as the worker

\footnotetext{
${ }_{16}$ Possible responses were: Firm did not use any ICT=1; Used ICT for some processes=2; Used ICT for most processes=3; Used ICT for all processes=4. Possible scores thus ranged from 4-16.
} 
shares. Interestingly, size is not important for the share of production workers using ICT-controlled machinery in Brazil, but the coefficient is both very significant and large in India. This suggests that larger Indian firms use more ICT intensive production processes relative to smaller Indian firms. The age of the firm mostly does not matter, except in Brazil, where older firms have higher ICT per worker and per unit of sales. The unionisation variable mostly enters insignificantly, except with regard to the usage index where it is significant and positive in both countries. This could obviously be interpreted in a number of ways and we return to this issue in more detail later in Section 5.

In terms of ownership, the multinational firm dummy is positively signed and significant for Brazil but this is not the case in India, except for non-production workers using PCs. In addition, there is clear evidence that foreign joint ventures use more ICT in India. This is not the case in Brazil. The difference may in part be explained by the limits on MNE operations in India which have led to greater use of joint ventures than in Brazil. Taking this into account, the results do suggest that firms with foreign ownership or participation are more likely to have higher ICT use or adoption.

As regards the association between our ICT measures and the occupation shares, we find that in Brazil more ICT intensive firms tend to have more administrative and other workers, although this is not generally the case for India. For the education shares, in Brazil the two ICT indices are strongly related to the share of upper secondary (US) and college educated production workers. The association is notably weaker in India. Further, in Brazil the share of non-production workers using PCs is very positively and significantly related with both the share of upper secondary (US) and college educated administrative workers. The share of production workers using ICT controlled machinery is also very strongly related to the share of educated production workers in Brazil. In India, we also find a positive association but one that is only strongly significant in the case of college educated production workers. These results suggest that ICT adoption has probably been associated with more skill-bias in Brazil than India ${ }^{17}$.

Finally, picking out the branch and region effects, we find that in both Brazil and India none of the branch dummies were significant ${ }^{18}$. In Brazil where the omitted region was Sao Paulo, we found that Minas Gerais was positive and significant at the $5 \%$ level, while Norde was negative but significant only at the $10 \%$ level. In India where the

\footnotetext{
17 These findings are explored in more detail in a complementary paper by Harrison (2006) using this dataset to look at the impact of technology adoption on skill shares and bias.

18 This reports results from the adoption estimate.
} 
omitted state was Maharashtra, all other states were negatively signed with four - Andhra Pradesh, Delhi, Gujerat and West Bengal - all significant at the 1\% level.

\section{ICT adoption and productivity}

We start by estimating some augmented Cobb-Douglas revenue functions estimated separately for Brazil and India. Revenues, $r_{t}$, is a function of physical capital, $K_{t}$, Labour, $L_{t}$, ICT capital, $I C T_{t}$ and a set of variables for observable firm heterogeneity given by $Z_{t}$ $r_{r i}=Z_{i}, K_{i}^{a} L_{i}^{\beta} I C T_{i}$

where the exponents give the elasticities of revenues with respect to the individual components.

Taking into logs with a normally distributed errort term, $e_{i}$

$\ln \left(r_{i}\right)=\ln \left(Z_{i}\right)+a \ln \left(K_{i}\right)+\beta \ln \left(L_{i}\right)+\gamma \ln \left(I C T_{i}\right)+e_{i}$

Introducing organisational change as an interaction with ICT capital gives:

$\ln \left(r_{i}\right)=\ln \left(Z_{i}\right)+a \ln \left(K_{i}\right)+\beta \ln \left(L_{i}\right)+\gamma \ln \left(I C T_{i}\right)^{*}(\mathrm{Org})+e_{i}$

Table 5 reports the results. All results include industry, region/state and age dummies unless otherwise specified. The estimations use the information available for 2003. Note that the number of observations in the Brazil sample has dropped to just below 200 due to the fact that many Brazilian firms only reported ranges rather than levels for key financial variables ${ }^{19}$. Appendix Table $A 5$ reports descriptive statistics for the variables used in the production function analysis.

The results reported in Table 5 appear to be robust and fairly similar for the two countries. Column (1) reports the basic production function with the addition of an ICT capital stock variable. All base variables are highly significant. The coefficients on materials are quite close to the median materials share in both countries. The coefficients on labour are, however, larger than the salary and wage shares. More importantly, the

\footnotetext{
${ }^{19} \mathrm{We}$ are in the process of correcting this limitation by matching our firms to the data in the Brazilian PIA or Industrial Census. This will allow us to retrieve values for the main financial variables used in the analysis. Appendix Table $A 4$ provides means for in and out of sample firms. While there are some significant differences with respect to the share of workers using PCs and, in Brazil the share of administrative and clerical workers in total employment, in general the table suggests that there are not large differences between in and out of sample firms.
} 
ICT capital stock is also highly significant in both cases, with a larger elasticity in Brazilian sample ${ }^{20}$.

We also use other measures of ICT. In particular, Column (2) of Table 5 replaces the ICT capital stock variable with dummy variables for the extent of ICT adoption, where the reference group is firms that only use desktop applications or do not use ICT at all. In Brazil the main impact is from firms using ICT in an integrated fashion (groups 4 and 5), which on average are about 50\% more productive than other firms. In India the main effect is from groups 3 and 4. This is consistent with the information on adoption patterns reported in the previous section. Column (3) then uses the ICT capital stock variable as well as the dummies for usage at the same time. Interestingly, the latter still contain a significant amount of information even after controlling for ICT capital stock.

An important feature to note from these specifications is that the coefficients on ICT capital correspond to extremely high median rates of return of about $2200 \%$ in Brazil and 2900\% in India (from Column (1)). This compares to more reasonable median rates of return of $65 \%$ and $72 \%$ for normal capital. While high returns to ICT investment have also been found in developed countries ${ }^{21}$, we still need to explain these apparently very high returns in our dataset. Although it is possible that a high cost of ICT capital due to depreciation and obsolescence may provide a partial explanation ${ }^{22}$, this is unlikely to be the whole story. More likely candidates are omitted observable and unobservable factors that may be correlated with ICT as well as measured or unmeasured complementary investments.

\subsection{Controlling for omitted variables}

One possible explanation for the very high returns to ICT capital that we find is that ICT is itself correlated with other omitted variables, such as skills and other firm characteristics, as suggested by the results reported in Table 4. To probe this in more detail, Table 6 reports not only the baseline production function (Column (1)) and then splits employment up by occupation (Column (2) and skill types (Column (3)). In addition, we augment (3) with a set of other controls for many important firm characteristics, including management practices, ownership, joint ventures, listed status

\footnotetext{
${ }^{20}$ Appendix Tables $A 6$ and $A 7$ report experimenting with the use of imputation and without, as well as the sensitivity of our results to dropping outliers and lower intensity users. They suggest that the results we get with imputation are similar to those we get without. Dropping firms with low usage indicators (Appendix Table A7) predictably and significantly lowers the return to ICT in both countries. Dropping outliers has the opposite effect while increasing the precision of the estimate.

${ }^{21}$ See, for example, Brynjolfsson and Hitt (2003); Stiroh (2002)

22 Stiroh (2004)
} 
and unionisation. For the India estimates, we also have a measure of software that is not available for the Brazilian firms and we hence control for investment in software as well. In Brazil the coefficients on labour of the different occupational groups are roughly in proportion to their employment shares. When production and administrative workers are split into college and non-college education, the coefficients are roughly equal across the four groups. In India, only the management and administrative occupation groups have positive coefficients and management is the only group with a consistently significant coefficient.

However, the results also suggest that these previously omitted variables can explain only a part of the high returns to ICT. They serve to reduce the coefficient on ICT by no more than 20-30\% in both Brazil and India. Interestingly, when we introduce the stock of software as an additional regressor (Column (5) for India) this reduces the coefficient on ICT by over 55\%. Software is extremely correlated with hardware (rho $=$ 0.82 ) and the two are jointly significant at the 5\% level. Even so, the implied median rate of return on ICT in India still remains very high at around 1100\%.

To eliminate other unobservable fixed effects that may be correlated with ICT, in Table 7 we proceed to estimate the same specifications in first differences using the change over a two-year period from 2001-2003. We then control in a similar way for occupation, skills and other controls. Column (1) in Table 7 is a levels specification on the same sample as the difference specification in Column (2). For Brazil the coefficient on ICT capital loses significance in the levels but is highly significant and large in the differences specification. For India, both coefficients are significant but there is decline in the change estimate. However, the estimated coefficient in India is still very large.. These results mean that firm-level fixed effects were not biasing the estimates of the levels specifications in both countries. Controlling for omitted occupation, skills and other controls has little, if any, effect on the ICT capital coefficient in either country. Further, software is now not significant in India ${ }^{23}$. Our finding that using first differences does not lower the ICT coefficients is indeed quite striking ${ }^{24}$.

\subsection{Complementary organisational changes}

As indicated in Section 2, one approach to understanding how ICT has an impact on performance is to focus on complementary investments, particularly with respect to the reorganisation of working practices and firm management. We now turn to investigating

${ }^{23}$ The change in software is less correlated with the change in hardware $(\mathrm{rho}=0.38)$ than in the levels.

${ }^{24}$ Stiroh (2004) does a meta-analysis and finds that estimates in first differences tend to be lower.] 
whether unmeasured complementary organisational changes can help explain the high measured returns to ICT and the possible contribution of such changes to performance. We use three measures of organisational change in the analysis that follows. The first is whether a firm "removed a level of hierarchy or reduced the number of reporting levels" and whether such change was explicitly related to IT over the past three years. This question was asked with regard to the working practices of three groups of employees: production workers as a whole; clerical and administrative workers and managers and its value could therefore range between 0 (no change) to 3 (change across all three occupation types). The second was whether a firm had "improved monitoring of individual workers or groups of workers" related to IT. The third was whether a firm had "improved management decision making based on up-to-date information". This third question was only asked with respect to changes in the working practices of managers and its value is either 0 or 1 .

The results presented in Table 8 show that in Brazil a reduction in hierarchy or flattening has no effect either directly or in the interaction for the full sample. However, once we exclude firms that make minimal or no use of ICT, we find a very strong and positive interaction (Column 4). For Brazilian firms that use ICT more intensively, the return to ICT capital stock is only significantly positive if they also undertake organisational change at the same time. In India there is again no effect from our measures of organisational change on the full sample, but when we exclude low-adopters we again find a significant direct effect of this type of organisational change on productivity growth ${ }^{25}$.

Table 9 performs the same exercise this time using the improved monitoring measure of organisational change. In neither country we find any effects. This suggests that the results from flattening reported above have not been driven by unobserved heterogeneity that is correlated with the propensity to undertake organisational change per se. Finally, Table 10 uses the management measure of organisational change. In Brazil there is no effect, while in India there is a significant direct effect, particularly for the high adopters.

In short, we find that organisational change linked to IT can have a significant impact on performance but that this depends on the type of organisational change as well as the degree of IT adoption. There is also some interesting variation across the two

\footnotetext{
${ }^{25}$ This is, of course, also consistent with complementarity between ICT adoption and organisational change, even though we find no significant interaction effect.
} 
countries. In particular, reduction in hierarchy exerts both a direct and indirect effect in Brazil, but only for firms that are using ICT for more complex functions. Improved monitoring is insignificant in all cases and improved management only comes in positively and significantly for the Indian sample.

\section{Variation across regions in ICT adoption}

A feature of many developing countries is the often weak institutional environment that exists. For example, in the context of ICT adoption and use, we can think of constraints - such as the level and predictability of taxation or the role of labour legislation - as potentially affecting not only adoption but also the subsequent impact on performance. To get a better sense of how such institutional barriers might come into play, our survey specifically asked whether - and to what extent - particular constraints had prevented firms from investing in ICT to their desired level over the last three years. Table 11 provides the descriptive statistics using region or state level averages. The constraints variables are defined as the proportion of firms in each state reporting that they are at all constrained by that factor. In Brazil the mean and median scores are generally closer together than in India, indicating much greater state/region level variation in the latter. The table also shows that skills availability, unions and labour regulations are actually perceived as more constraining on average in Brazil than in India. It is striking that just under $55 \%$ of Brazilian firms reported skills availability as a constraint. This is broadly consistent with other evidence on labour supply and its quality. With regard to unions, branch data show that - with the notable exception of machine tools - unionisation rates in Brazil are indeed higher than in India ${ }^{26}$.

The scores for the availability and pricing of Internet services and the level of Internet use for suppliers/customers are very similar for both countries, while lack of government support is perceived as more of a constraint in Brazil. This may appear surprising given the large investments in connectivity and the like made by the Brazilian government. However, it may also signal the link to expectations. In India, firms may have a low expectation of government support and discount it appropriately. Finally, for India, we have an additional variable - the number of days in both 2001 and 2003 that a given firm experienced problems with power supply - that has the advantage of being

\footnotetext{
${ }^{26}$ In India, unionisation rates in 2000 ranged from under 10\% in wearing apparel and soaps and detergents to $74 \%$ in machine tools. The unweighted average for the six branches was $26 \%$. In Brazil, the range was from $22-47 \%$ with the average at $35 \%$.
} 
exogenous $^{27}$. The mean number of days - nearly 22 - with power supply problems in 2001 is indeed quite high. Exploiting this information on the variation in constraints across regions to investigate the impact of external conditions on the adoption of ICT and subsequently the qualified returns to ICT adoption, can help identify policy choices.

Using such measures of constraints in explaining performance can obviously be problematic given the need to control for potential endogeneity, particularly as the performance variables have been gathered simultaneously. ${ }^{28}$. With our dataset, this is a serious challenge as, for example, using lagged values is not feasible. To mitigate these problems, we use regional/state average values for the constraints in our estimations.

We start by using the India data and the power supply measure to look at the impact of mean state level days in 2001 affected by power disruptions on ICT adoption (Table 12). All the variables used in Table 4 are also included as controls but not reported. All standard errors in this section are adjusted for clustering at the state/region level. Panel A reports results for the level of ICT adoption in 2003. As before, Columns (1) and (2) are estimated with Ordered Probit, while all the others are estimated using OLS. We find some clear evidence of lower adoption in states more affected by power disruptions, particularly for the overall adoption index and the log of ICT per unit of sales. Both variables are negative signed and significant. Panel B reports results from the changes. Again, there is some evidence for smaller increases in usage, but surprisingly we get a small positive - but insignificant - coefficient on the change in the log of ICT capital intensity.

\subsection{Variation across regions in the returns to ICT}

We now look at the impact of constraints on performance. Table 13 allows the elasticity with respect to ICT capital to vary by interacting it with the power supply variable, both mean and median values. The interaction is strongly negative. Not only do firms in more power-disrupted states invest less in ICT, they also get a lower return. Not only are the elasticities lower but so are the implied rates of return. Figure 4 allows the elasticity to be different for each state and plots the state-specific estimated elasticity against the state

\footnotetext{
${ }^{27}$ It could be argued that this variable is not strictly exogenous in that the frequency of power cuts could have affected the location decision. However, as the great majority of our firms were not established recently and the frequency of power cuts has varied substantially over time, it seems unlikely that this is a major hurdle.

${ }^{28}$ For how to do this with subjective survey data, see Commander and Svejnar (2006). See also Carlin et al (2006). A possible alternative would be to use an instrumental variable, such as the ratio of workers with university and secondary education. If production is Cobb-Douglas, the firm is a profit maximiser and a price taker for inputs, then the ratio of input prices (wages) can be considered exogenous
} 
mean number of days in 2001 with power-related problems. The fit is very good with an R-squared of $0.80^{29}$. It can be seen that all the South Indian states - with the exception of Karnataka - have relatively high elasticities that are closer to the Brazil estimates, while the Northern and Eastern states (plus Karnataka) have low or zero estimated elasticities.

An obvious question that arises is whether we are actually identifying the impact of power shortages or the fact that our measure is just correlated across states with other institutional and infrastructure factors. Appendix Table 10 shows that the power distuption variable is generally highly correlated across states with the state means of the individual constraints. These constraints are even more highly correlated with each other. This raises the possibility that there are a cluster of states with poor institutions that are correlated with each other. This seems to be consistent with evidence from other sources $^{30}$. However, at this stage, we are probably not able to identify exactly which factors are important since we only have observations from nine different states.

Table 14 extends this discussion by showing that we get similar results to those in Table 13 if we enter the constraints variables individually, instead of using the power distuption variable. For India, only unions and internet access are not at all significant ${ }^{31}$. If we include more than one interaction of constraints, they become individually insignificant but jointly significant, which is hardly surprising given that they are highly correlated. Further, if we also include the power disruption variable it always dominates making the other constraints variables insignificant.

Table 15 does the same exercise for Brazil. In this case, we get much less traction. Only the interaction of unions and ICT is mildly significant but this is in fact driven entirely by just three observations from one - Centro - of the regions. Figure 3 shows that when we drop these observations, there is no association. Further, given that over 60\% of our observations are in the Sao Paulo and Sul regions that have very similar elasticities, we are unlikely to be able to identify regional variation in constraints as playing any significant role in explaining returns to ICT in Brazil ${ }^{32}$.

In sum, the novel use of constraints measures to look at both the consequences for adoption and performance, suggests that in India weak institutions do indeed result

\footnotetext{
${ }^{29}$ In a bi-variate regression (with clustered standard errors) of the elasticity on the disruption variable the coefficient (standard error) is -0.009 (0.001), very similar to the interaction term in column (1) of Table 13. ${ }^{30}$ See, for example, the World Bank's Doing business reports

${ }^{31}$ Note that in all cases if we also include an interaction with the disruptions variable this always dominates and the constraints interaction becomes insignificant.

32 We also experimented with a more restrictive use of the constraints variables to see whether the perceived intensity of the constraint mattered. We ran the same estimations for when the constraints score was either 3 or 4 (viz to some extent and to a large extent). The results were very similar, although the point estimates were predictably higher.
} 
in lowering ICT adoption as well as the returns from ICT adoption. Interestingly, however, the best Indian states look quite like the main Brazilian regions. Aside from indicating far less variation in regional institutions in Brazil than in India, our analysis also picks out the way in which this state-level variation in India translates directly into weaker adoption and performance. For example, comparing firms of comparable dimensions in the same branch but located in states with different institutional features, a firm located in a state with good institutions - Tamil Nadu - could expect to have almost three times higher ICT intensity and almost twice the rate of return to its ICT investment when compared with a firm in West Bengal - a state with relatively weak institutions. The state with better institutions - Tamil Nadu - is, moreover, quite similar in both intensity of ICT use and in its rate of return to ICT to Brazilian states, such as Minas Gerais and Sao Paulo.

\section{Conclusion}

This paper uses a unique, new dataset that we have collected on a thousand firms in manufacturing in two important developing countries, Brazil and India. The data allow us to look at the extent of ICT adoption at the firm level, to examine the characteristics of firms adopting ICT and the consequences of adoption for performance. In addition, we are able to relate adoption and the return to adoption to region or state level institutional features in both countries. In terms of adoption, we find that size and foreign ownership tend to be associated with higher adoption. In Brazil, we also find that there is strong evidence that ICT adoption has been associated with a higher share of educated workers. Interestingly, Brazilian firms also report skills availability as a constraint; a finding that is in keeping with other observations about the shortcomings of the Brazilian educational system. In India the positive association between ICT adoption and education exists, but in more attenuated form. The evidence shows that Brazilian firms have on average adopted more ICT than their Indian counterparts and use that ICT more intensively. However, firms operating in states with good institutional arrangements in India tend to have adoption rates similar to their Brazilian comparators. Certainly, the variation between countries in adoption is far smaller than the aggregate data would suggest.

With respect to the association between ICT and productivity, our analysis suggests that - in line with some of the evidence from developed countries - there have been very high returns to ICT. We investigate possible reasons for the very high returns 
that we report for both Brazilian and Indian firms. We find that these high returns persist even after including skills, occupation, management practices and other controls. We also look at the way in which complementary changes - such as in the organisation of work practices - might have affected the returns to ICT. We find robust and positive evidence that there is complementarity between some - but not all - of our organisational change measures. In particular, reducing hierarchies appears to be associated with higher returns to ICT in Brazil, and is directly positively related to productivity growth in India. The evidence also suggests that this positive effect only kicks in above a certain threshold level of adoption. Low intensity users of ICT - still a major share of firms in both Brazil and India - receive little or no positive impact.

Finally, our survey allows us to throw new light on the way in which institutional features of a region or state may affect both ICT adoption decisions and returns to ICT adoption. We find that the combination of weak institutions and infrastructure result in lower adoption and lower returns, particularly in India. The regional variation in Brazil is far smaller. However, firms in India located in states with better institutions and infrastructure have returns to ICT that are close to those obtained by Brazilian firms. This suggests that much of the policy challenge in India consists of addressing the sources at state level of these inefficiencies and institutional weakness. 


\section{Appendix 1: Design of the survey}

The survey was administered to 500 firms each in Brazil and India on a face-to-face basis in April and May, 2005. The firms were selected in six branches of manufacturing: electronic components, plastic products, soap and detergents, auto-parts, machine tools and wearing apparel. In India the sampling frame comprised the Prowess and First source databases of firms. Stratification was by branch and region. In India, the Prowess dataset contains extensive financial data on each firm, so this was used as the primary source for sampling. For branch, quotas were set relative to their size. The Prowess universe comprised 437 firms of which 175 were sampled. The remaining 325 were taken from First Source. The order used to achieve these quotas was thus from industry or branch to Prowess and First Source (in that order) and then by region. Within the final regional quota cell, firms were selected randomly. In terms of regions, sampling was organised in 14 regional centres located in nine states in India. In Brazil, the sampling frame was the Industrial Census (PIA). Stratification was by branch, region and employment size. Sampling occurred in five regions of the country comprising 13 states.

\section{Appendix 2: Variable definitions}

ICT adoption index: takes integer values from 1 to 5 according to answers to the question 'how would you describe the degree of ICT usage in your firm?' where the options are as follows: (1) ICT is not used at all; (2) ICT is used for some office applications along with accessing the internet, emailing etc.; (3) ICT is used for some advanced applications, most processes are automated but there is no integration into a central system; (4) most processes are automated and some of them are integrated into a central system; (5) almost all processes are automated and integrated into a central system.

ICT usage index: takes integer values from 4 to 16. For each of four functions (accounting services; inventory management; marketing and product design; production process) firms were asked to chose from the following four options: (1) do not use any ICT; (2) use ICT for some processes; (3) use ICT for most processes; (4) use ICT for all processes. The variable is the sum of these answers across the four different functions.

ICT capital stock: constructed using a perpetual inventory method from information on ICT capital investment in 2001, 2002 and 2003. The assumed depreciation rate is 0.315 and the price of ICT capital is assumed to fall by $20 \%$ per year (both following Stiroh, 
2004). For the initial stock real ICT capital investment is assumed to have been growing by $50 \%$ a year for both countries, which is close to the median growth rate in the sample during the 2001-2003 period.

Admin: the proportion of the workforce in 2003 that were administrative and clerical workers.

Managers: the proportion of the workforce in 2003 that were managers.

Other: the proportion of the workforce in 2003 that were not production workers, administrative and clerical workers or managers.

Prod:US: the proportion of production workers in 2003 that had completed Upper Secondary but not College.

Prod:Coll: the proportion of production workers in 2003 that had completed College.

Admin:US: the proportion of admin and clerical workers in 2003 that had completed Upper Secondary but not College.

Admin:Coll: the proportion of admin and clerical workers in 2003 that had completed College.

Union: dummy variable equal to one if the firm reported that any of its workforce belonged to a union.

OC (Flattening): takes integer values from 0 to 3 according to whether firms reported that they had 'removed a level of hierarchy or reduced the number of reporting levels' for three types of workers (production; admin and clerical; managers) during the years 2001, 2002 or 2003.

OC (Improved monitoring): takes integer values from 0 to 3 according to whether firms reported that they had introduced improved monitoring of individual workers or groups of workers' for three types of workers (production; admin and clerical; managers) during the years 2001, 2002 or 2003. 
OC (Improved monitoring): takes values of 0 or 1 according to whether firms reported that they had introduced improved management decision making based on up-to-date information' during the years 2001, 2002 or 2003.

Mean days disrupted: (India only) the State mean number of days in 2001 that firms reported experiencing 'power related problems (power cuts or surges, either partial or total) from the public grid'.

Median days disrupted: (India only) the State median number of days in 2001 that firms reported experiencing 'power related problems (power cuts or surges, either partial or total) from the public grid'.

Reported constraints: in each case these are equal to the state/region proportion of firms answering that the potential constraint in question had constrained them at all from adopting ICT to their preferred level over the past three years. The only exception is Availability of skills which is the average for four types of constraints related to skill shortages: 'lack of production workers with relevant skills'; 'lack of IT technicians with relevant skills'; 'lack of clerical and administrative workers with relevant skills'; 'lack of managers with relevant skills'. 


\section{References}

Bartel, Ann, C. Ichniowski and K. Shaw (2005), "How does information technology really affect productivity? Plant-level comparisons of product innovation, process improvement and worker skills, NBER Working Paper 11773

Basu, Susanto, Fernald, John G., Oulton, Nicholas and Srinivasan, Sylaja (2003) "The case of the missing productivity growth: or, does information technology explain why productivity accelerated in the United States but not the United Kingdom?" NBER Macro-economics Annual.

Black, Sandra and Lisa Lynch, (2001), "How to compete: the impact of workplace practices and information technology on productivity", Review of Economics and Statistics, August, 434-445

Bloom, Nick and Van Reenen, John (2006) "Measuring and explaining management practices across firms and countries", Centre for Economic Performance Working Paper No.716.

Bloom, Nick, Rafaella Sadan and John Van Reenen, (2006) “It ain't what you do, it's the way you do I.T: Investigating the productivity miracle using US multinationals", Centre for Economic Performance, April, mimeo

Breshnahan, Tim, Brynjolfsson, Erik and Hitt, Lorin (2002) "Information technology, workplace organization and the demand for skilled labor", Quarterly Journal of Economics, 117(1), 339-76.

Brynjolfsson, Erik and Hitt, Lorin (2000) " Beyond computation: information technology, organisational transformation and business performance", Journal of Economic Perspectives, vol.14, no.4, 23-48.

Brynjolfsson, Erik and Hitt, Lorin (2004) "Computing productivity: firm level evidence", Review of Economics and Statistics, 85(4), 793-808.

Brynjolfsson, Erik, Hitt, Lorin and Yang, Shinkyu (2002) "Intangible assets: computers and organizational capital", MIT Sloan Paper 138.

Commander, Simon and Jan Svejnar, (2006) "Institutions, Ownership and Competition: The Efficiency of firms in 26 transition economies", EBRD and University of Michigan, May, mimeo

Doms, M., Dunn, W., Oliner, S. and Sichel, D. (2004) "How fast do personal computers depreciate? Concepts and new estimates", NBER Working Papers, no.1010521.

Geroski, Paul (2000), “Models of technology diffusion”, Research Policy, 29, 603-625

Harrison, Rupert, (2006), "Skill biased technology adoption: firm level evidence from Brazil and India, Institute for Fiscal Studies, May, mimeo

Jorgenson, Dale and Stiroh, Kevin (2000) "Raising the speed limit: US economic growth in the information age", Brookings Papers on Economic Activity, 1:125-211. 
Jorgenson, D.W. (2001) "Information technology and the US economy", American Economic Review, 91(1), 1-32.

Oliner, Stephen and Sichel, Daniel (2000) "The resurgence of growth in the late 1990s: is information technology the story?", Journal of Economic Perspectives, 14(4), 3-22.

Stiroh, Kevin (2002) "Information technology and the US productivity revival: what do the industry data say?", American Economic Review, 92(5), December 1559-76.

Stiroh, Kevin (2004), "Reassessing the role of IT in the production function: A meta analysis", Federal Reserve Bank of New York, mimeo

World Bank, 2006, "Information and Communication for Development: Global trends and Policies", Washington DC 
Table 1: Descriptive statistics for full sample

\begin{tabular}{lcccccccc}
\hline & \multicolumn{3}{c}{ Brazil } & & & \multicolumn{2}{c}{ India } \\
& Mean & Median & s.d & Obs & Mean & Median & s.d & Obs. \\
\hline Employment & 207 & 70 & 431 & 387 & 367 & 70 & 1074 & 476 \\
\% change in Emp & 22.0 & 7.8 & 63.2 & 368 & 19.7 & 14.3 & 37.7 & 471 \\
\% change in Sales & 57.8 & 25.0 & 128.0 & 294 & 31.8 & 23.1 & 56.5 & 447 \\
Materials share & 0.44 & 0.41 & 0.31 & 194 & 0.41 & 0.40 & 0.25 & 433 \\
Wage share & 0.22 & 0.16 & 0.25 & 195 & 0.09 & 0.05 & 0.14 & 446 \\
Capital intensity & 0.75 & 0.32 & 1.19 & 156 & 0.56 & 0.25 & 1.03 & 395 \\
& & & & & & & &
\end{tabular}

Notes: Levels are for 2003 and changes are for the 2-year period 2001-2003. A small number of outliers are excluded from the above calculations as follows: \% change in sales greater than $1000 \%$ over the two-year period; materials share greater than 2; wage share greater than 2, capital intensity greater than 10 .

Figure 1: Summary index of ICT adoption, 2001 and 2003

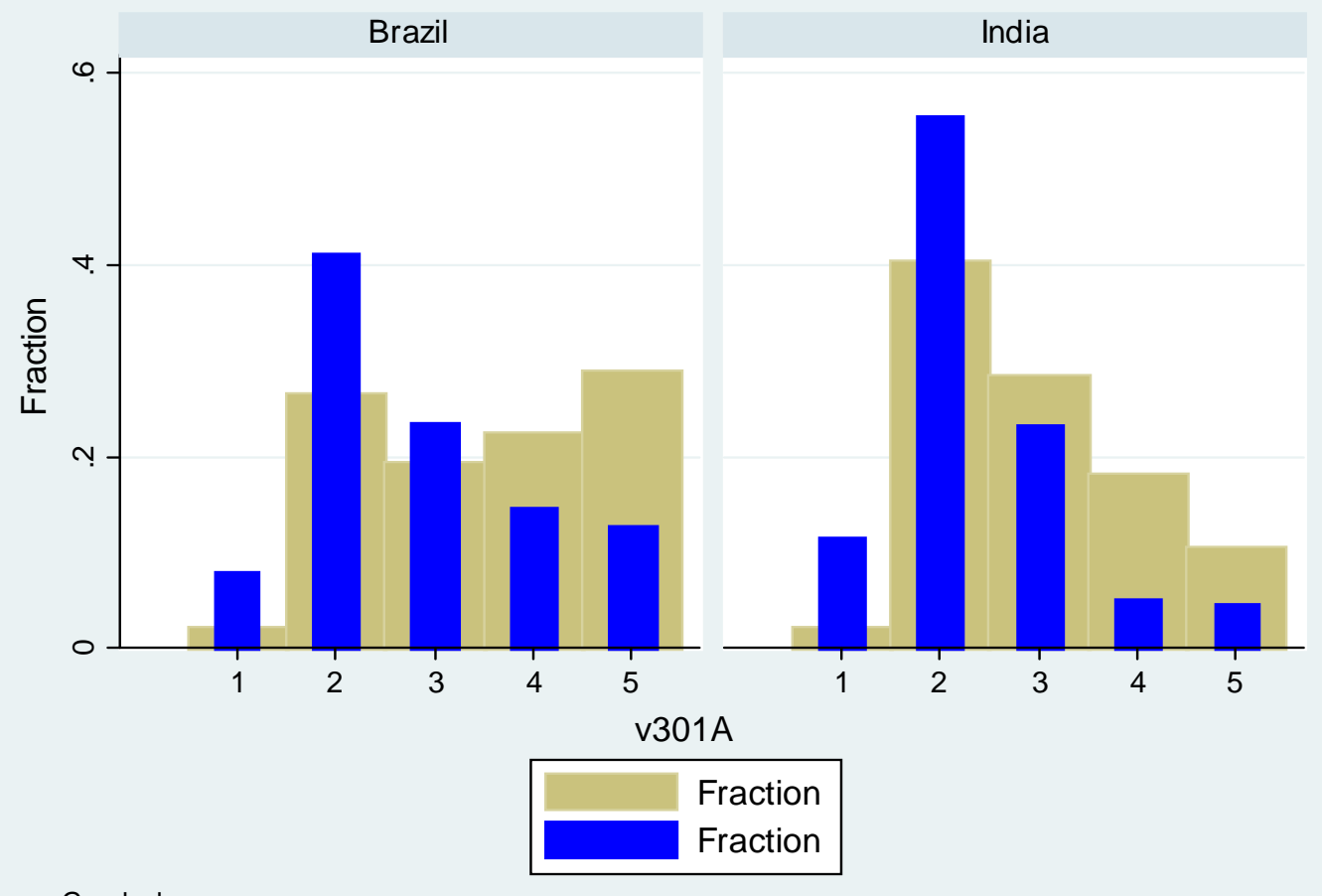

Notes: thin bars are for 2001, thick bars for 2003; 
Figure 2: Date of first introduction: PCs

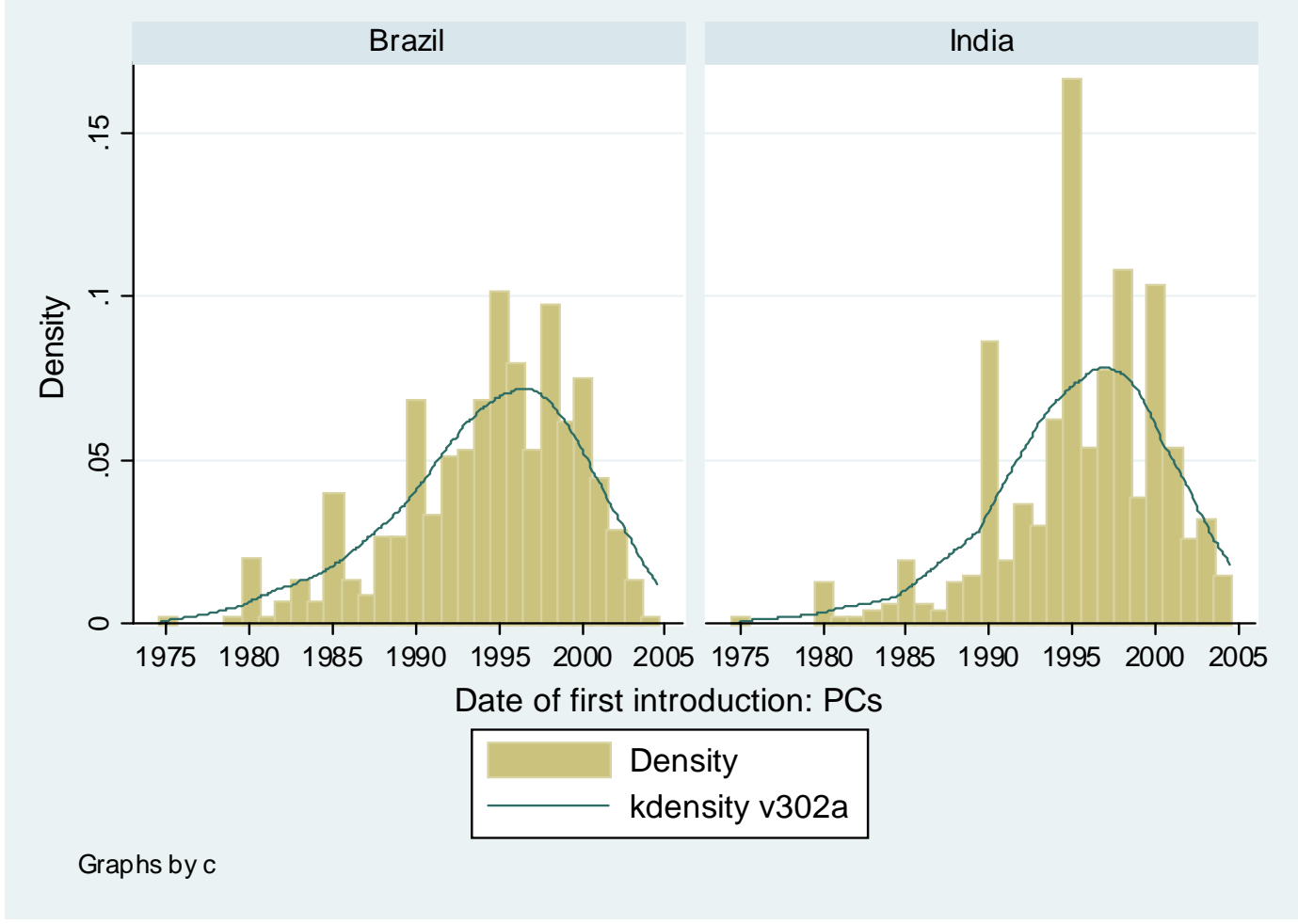

Figure 3: Date of first introduction: Servers

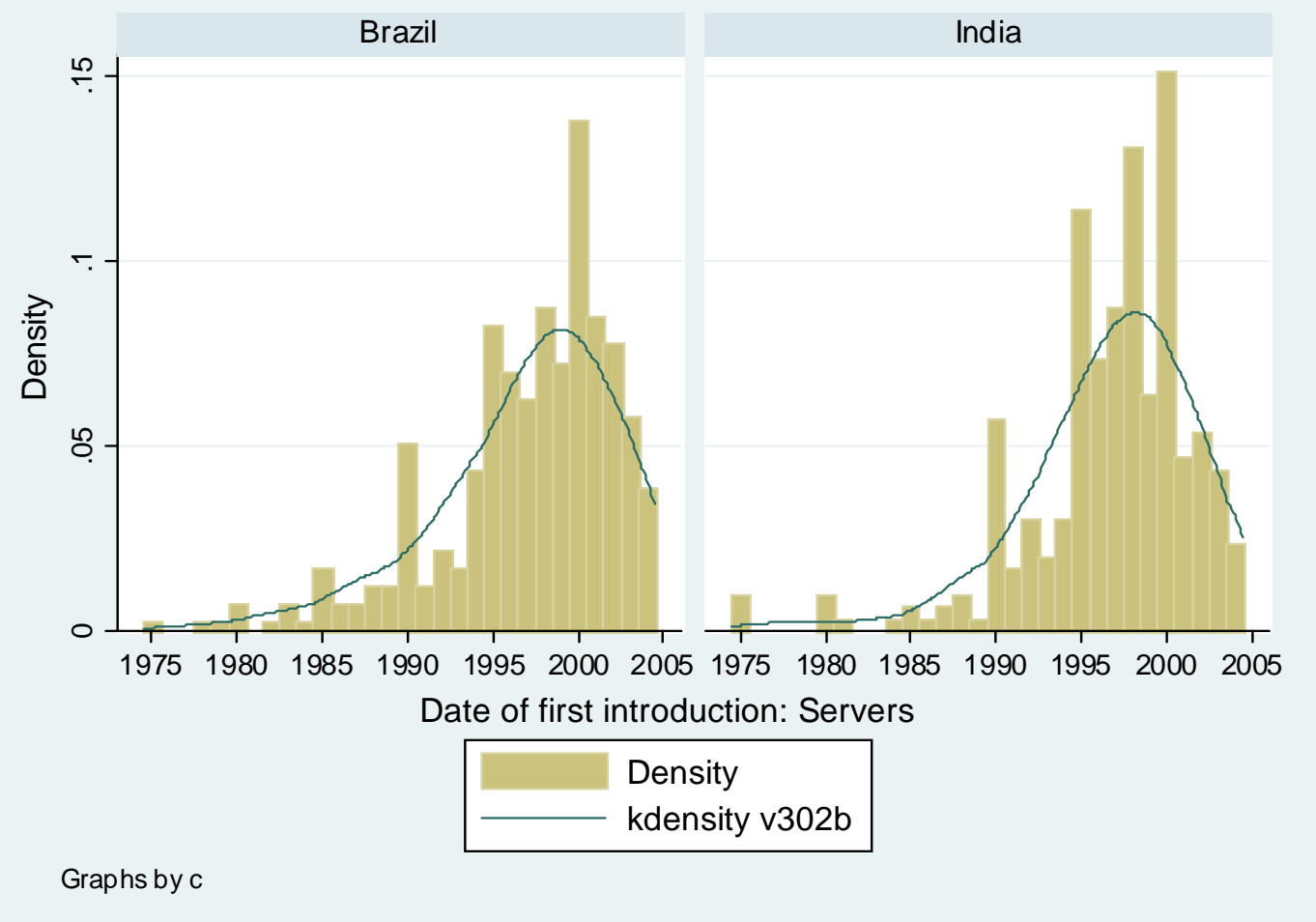


Table 2: Measures of ICT adoption in 2003

\begin{tabular}{|c|c|c|c|c|c|c|c|c|}
\hline & \multicolumn{4}{|c|}{ Brazil } & \multicolumn{4}{|c|}{ India } \\
\hline & Mean & Median & s.d & Obs & Mean & Median & s.d & Obs. \\
\hline \multicolumn{9}{|l|}{ Summary measures } \\
\hline Adoption index & 3.50 & 4 & 1.22 & 491 & 2.94 & 3 & 1.05 & 476 \\
\hline Usage index & 11.64 & 12 & 3.48 & 461 & 10.71 & 10 & 3.36 & 473 \\
\hline \multicolumn{9}{|l|}{ Hardware } \\
\hline ICT capital as \% of sales & 4.18 & 0.59 & 17.78 & 278 & 3.34 & 0.44 & 17.01 & 379 \\
\hline PCs per employee & 0.28 & 0.20 & 0.29 & 379 & 0.22 & 0.15 & 0.25 & 473 \\
\hline Servers per employee & 0.04 & 0.02 & 0.07 & 372 & 0.02 & 0.00 & 0.05 & 473 \\
\hline \multicolumn{9}{|l|}{ Workforce usage } \\
\hline $\begin{array}{l}\text { \% of non-production workers } \\
\text { using PCs }\end{array}$ & 69.6 & 90.0 & 37.9 & 484 & 53.9 & 59 & 34.6 & 476 \\
\hline $\begin{array}{l}\% \text { of production workers } \\
\text { using ICT-controlled mach. }\end{array}$ & 23.3 & 10 & 31.2 & 468 & 15.3 & 6 & 23.3 & 473 \\
\hline
\end{tabular}

Notes: for ICT capital as a \% of sales a small number of outliers are excluded with ICT capital as a \% of sales greater than $300 \%$.

Table 3: Change in ICT adoption, 2001-2003

\begin{tabular}{|c|c|c|c|c|c|c|c|c|}
\hline & \multicolumn{4}{|c|}{ Brazil } & \multicolumn{4}{|c|}{ India } \\
\hline & Mean & Median & s.d & Obs & Mean & Median & s.d & Obs. \\
\hline \multicolumn{9}{|l|}{ Summary measures } \\
\hline Adoption index & 0.68 & 0 & 0.92 & 482 & 0.59 & 0 & 0.78 & 475 \\
\hline Usage index & 1.39 & 0 & 2.26 & 448 & 1.69 & 0 & 2.34 & 473 \\
\hline \multicolumn{9}{|l|}{ Hardware } \\
\hline ICT capital as \% of sales & 2.06 & 0.27 & 12.74 & 273 & 2.01 & 0.19 & 13.32 & 430 \\
\hline PCs per employee & 0.07 & 0.05 & 0.15 & 349 & 0.07 & 0.03 & 0.14 & 470 \\
\hline Servers per employee & 0.007 & 0.001 & 0.051 & 346 & 0.004 & 0.000 & 0.033 & 470 \\
\hline \multicolumn{9}{|l|}{ Workforce usage } \\
\hline $\begin{array}{l}\text { \% of non-production workers } \\
\text { using PCs }\end{array}$ & 12.5 & 0 & 20.9 & 462 & 14.2 & 10 & 19.4 & 476 \\
\hline $\begin{array}{l}\% \text { of production workers } \\
\text { using ICT-controlled mach. }\end{array}$ & 9.0 & 0 & 19.5 & 456 & 6.7 & 0 & 14.5 & 472 \\
\hline
\end{tabular}

Notes: for ICT capital as a \% of sales a small number of outliers are excluded with ICT capital as a \% of sales greater than $300 \%$ in either 2001 or 2003 . 
Table 4: Correlates of adoption

\begin{tabular}{|c|c|c|c|c|c|c|}
\hline Panel A: Brazil & $\begin{array}{l}\text { (1) } \\
\text { Adoption }\end{array}$ & $\begin{array}{l}\text { (2) } \\
\text { Usage }\end{array}$ & $\begin{array}{l}\text { (3) } \\
\text { \%usingPCs }\end{array}$ & $\begin{array}{l}\text { (4) } \\
\text { \%usingMch }\end{array}$ & $\begin{array}{l}\text { (5) } \\
\ln (\text { ict/emp) }\end{array}$ & $\begin{array}{l}(6) \\
\ln (\mathrm{ict} / \mathrm{y})\end{array}$ \\
\hline 30-250 emp & $\begin{array}{l}0.640 \\
(0.181)^{* * *}\end{array}$ & $\begin{array}{l}0.812 \\
(0.170)^{* * *}\end{array}$ & $\begin{array}{l}11.885 \\
(5.627)^{* *}\end{array}$ & $\begin{array}{l}-1.325 \\
(4.482)\end{array}$ & $\begin{array}{l}-0.442 \\
(0.265)^{*}\end{array}$ & $\begin{array}{l}-0.485 \\
(0.340)\end{array}$ \\
\hline $250+$ emp & $\begin{array}{l}1.551 \\
(0.233)^{* * *}\end{array}$ & $\begin{array}{l}1.421 \\
(0.215)^{* * *}\end{array}$ & $\begin{array}{l}24.076 \\
(6.638)^{* * *}\end{array}$ & $\begin{array}{l}8.265 \\
(6.022)\end{array}$ & $\begin{array}{l}-0.324 \\
(0.314)\end{array}$ & $\begin{array}{l}-0.359 \\
(0.399)\end{array}$ \\
\hline mne & $\begin{array}{l}0.657 \\
(0.389)^{*}\end{array}$ & $\begin{array}{l}0.711 \\
(0.341)^{* *}\end{array}$ & $\begin{array}{l}13.850 \\
(9.697)\end{array}$ & $\begin{array}{l}16.646 \\
(14.888)\end{array}$ & $\begin{array}{l}-0.528 \\
(0.365)\end{array}$ & $\begin{array}{l}0.804 \\
(1.106)\end{array}$ \\
\hline so & $\begin{array}{l}0.198 \\
(0.485)\end{array}$ & $\begin{array}{l}0.512 \\
(0.473)\end{array}$ & $\begin{array}{l}-18.481 \\
(12.116)\end{array}$ & $\begin{array}{l}-9.116 \\
(8.151)\end{array}$ & $\begin{array}{l}0.631 \\
(0.706)\end{array}$ & $\begin{array}{l}0.367 \\
(0.802)\end{array}$ \\
\hline listed & $\begin{array}{l}0.146 \\
(0.256)\end{array}$ & $\begin{array}{l}0.514 \\
(0.431)\end{array}$ & $\begin{array}{l}-9.740 \\
(7.042)\end{array}$ & $\begin{array}{l}4.984 \\
(7.122)\end{array}$ & $\begin{array}{l}0.776 \\
(0.542)\end{array}$ & $\begin{array}{l}0.660 \\
(0.809)\end{array}$ \\
\hline jvd & $\begin{array}{l}-0.435 \\
(0.139)^{* * *}\end{array}$ & $\begin{array}{l}0.179 \\
(0.126)\end{array}$ & $\begin{array}{l}8.445 \\
(4.100)^{* *}\end{array}$ & $\begin{array}{l}1.591 \\
(3.738)\end{array}$ & $\begin{array}{l}-0.324 \\
(0.232)\end{array}$ & $\begin{array}{l}-0.567 \\
(0.303)^{*}\end{array}$ \\
\hline jvf & $\begin{array}{l}-0.018 \\
(0.223)\end{array}$ & $\begin{array}{l}0.030 \\
(0.215)\end{array}$ & $\begin{array}{l}-0.069 \\
(5.867)\end{array}$ & $\begin{array}{l}5.031 \\
(6.079)\end{array}$ & $\begin{array}{l}-0.200 \\
(0.277)\end{array}$ & $\begin{array}{l}-0.654 \\
(0.465)\end{array}$ \\
\hline union & $\begin{array}{l}0.143 \\
(0.132)\end{array}$ & $\begin{array}{l}0.258 \\
(0.122)^{* *}\end{array}$ & $\begin{array}{l}-0.238 \\
(4.067)\end{array}$ & $\begin{array}{l}1.882 \\
(3.643)\end{array}$ & $\begin{array}{l}-0.086 \\
(0.217)\end{array}$ & $\begin{array}{l}-0.341 \\
(0.293)\end{array}$ \\
\hline Admin & $\begin{array}{l}0.020 \\
(0.005)^{* * *}\end{array}$ & $\begin{array}{l}0.019 \\
(0.005)^{* * *}\end{array}$ & $\begin{array}{l}0.427 \\
(0.137)^{* * *}\end{array}$ & $\begin{array}{l}0.320 \\
(0.160)^{* *}\end{array}$ & $\begin{array}{l}0.021 \\
(0.008)^{* *}\end{array}$ & $\begin{array}{l}0.008 \\
(0.013)\end{array}$ \\
\hline Managers & $\begin{array}{l}-0.018 \\
(0.012)\end{array}$ & $\begin{array}{l}-0.012 \\
(0.011)\end{array}$ & $\begin{array}{l}-0.239 \\
(0.471)\end{array}$ & $\begin{array}{l}0.371 \\
(0.343)\end{array}$ & $\begin{array}{l}0.029 \\
(0.016)^{*}\end{array}$ & $\begin{array}{l}0.034 \\
(0.019)^{*}\end{array}$ \\
\hline Other & $\begin{array}{l}0.022 \\
(0.005) * * *\end{array}$ & $\begin{array}{l}0.015 \\
(0.005)^{* * *}\end{array}$ & $\begin{array}{l}0.063 \\
(0.141)\end{array}$ & $\begin{array}{l}0.197 \\
(0.155)\end{array}$ & $\begin{array}{l}-0.006 \\
(0.010)\end{array}$ & $\begin{array}{l}-0.004 \\
(0.014)\end{array}$ \\
\hline Prod: US & $\begin{array}{l}0.005 \\
(0.002)^{* *}\end{array}$ & $\begin{array}{l}0.008 \\
(0.002)^{* * *}\end{array}$ & $\begin{array}{l}0.047 \\
(0.067)\end{array}$ & $\begin{array}{l}0.245 \\
(0.059)^{* * *}\end{array}$ & $\begin{array}{l}0.003 \\
(0.004)\end{array}$ & $\begin{array}{l}-0.001 \\
(0.004)\end{array}$ \\
\hline Prod: Coll & $\begin{array}{l}0.018 \\
(0.006)^{* * *}\end{array}$ & $\begin{array}{l}0.024 \\
(0.009)^{* * *}\end{array}$ & $\begin{array}{l}0.113 \\
(0.136)\end{array}$ & $\begin{array}{l}0.554 \\
(0.239)^{* *}\end{array}$ & $\begin{array}{l}0.019 \\
(0.008)^{* *}\end{array}$ & $\begin{array}{l}0.012 \\
(0.011)\end{array}$ \\
\hline Admin: US & $\begin{array}{l}0.005 \\
(0.003)\end{array}$ & $\begin{array}{l}0.002 \\
(0.003)\end{array}$ & $\begin{array}{l}0.247 \\
(0.099)^{* *}\end{array}$ & $\begin{array}{l}-0.067 \\
(0.074)\end{array}$ & $\begin{array}{l}-0.000 \\
(0.005)\end{array}$ & $\begin{array}{l}0.002 \\
(0.006)\end{array}$ \\
\hline Admin: Coll & $\begin{array}{l}0.001 \\
(0.003)\end{array}$ & $\begin{array}{l}0.006 \\
(0.003)^{* *}\end{array}$ & $\begin{array}{l}0.281 \\
(0.108)^{* * *}\end{array}$ & $\begin{array}{l}-0.073 \\
(0.077)\end{array}$ & $\begin{array}{l}0.005 \\
(0.005)\end{array}$ & $\begin{array}{l}0.005 \\
(0.006)\end{array}$ \\
\hline Age $<10$ & $\begin{array}{l}-0.108 \\
(0.149)\end{array}$ & $\begin{array}{l}0.119 \\
(0.147)\end{array}$ & $\begin{array}{l}3.311 \\
(4.390)\end{array}$ & $\begin{array}{l}2.809 \\
(3.863)\end{array}$ & $\begin{array}{l}0.494 \\
(0.232) * *\end{array}$ & $\begin{array}{l}0.325 \\
(0.297)\end{array}$ \\
\hline Age $11-20$ & $\begin{array}{l}-0.084 \\
(0.161)\end{array}$ & $\begin{array}{l}-0.198 \\
(0.148)\end{array}$ & $\begin{array}{l}4.763 \\
(4.497)\end{array}$ & $\begin{array}{l}4.486 \\
(4.264)\end{array}$ & $\begin{array}{l}0.476 \\
(0.240)^{* *}\end{array}$ & $\begin{array}{l}0.710 \\
(0.313)^{* *}\end{array}$ \\
\hline $\begin{array}{l}\text { Observations } \\
\text { R-squared }\end{array}$ & 358 & 358 & $\begin{array}{l}358 \\
0.23\end{array}$ & $\begin{array}{l}358 \\
0.24\end{array}$ & $\begin{array}{l}256 \\
0.21\end{array}$ & $\begin{array}{l}226 \\
0.16\end{array}$ \\
\hline
\end{tabular}




\begin{tabular}{|c|c|c|c|c|c|c|}
\hline \multirow[t]{2}{*}{ Panel B: India } & $(1)$ & (2) & (3) & (4) & (5) & (6) \\
\hline & Adoption & Usage & \%usingPCs & \%usingMch & $\ln (\mathrm{ict} / \mathrm{emp})$ & $\ln (\mathrm{ict} / \mathrm{y})$ \\
\hline \multirow[t]{2}{*}{ 30-250 emp } & 0.457 & 0.396 & 3.797 & 10.511 & -0.310 & -0.565 \\
\hline & $(0.150)^{* * *}$ & $(0.137)^{* * *}$ & $(4.002)$ & $(1.940)^{* * *}$ & $(0.180)^{*}$ & $(0.234)^{* *}$ \\
\hline \multirow[t]{2}{*}{ 250+ emp } & 1.126 & 0.723 & 11.532 & 19.855 & -0.590 & -0.671 \\
\hline & $(0.198) * * *$ & $(0.175)^{* * *}$ & $(5.156)^{* *}$ & $(3.626) * * *$ & $(0.276)^{* *}$ & $(0.349)^{*}$ \\
\hline \multirow[t]{2}{*}{ mne } & 0.137 & 0.390 & 11.733 & 0.029 & -0.290 & 0.190 \\
\hline & $(0.254)$ & $(0.271)$ & $(7.002)^{*}$ & (6.637) & $(0.383)$ & $(0.714)$ \\
\hline \multirow[t]{2}{*}{ so } & -0.168 & 0.185 & -12.091 & 2.321 & 0.410 & 1.325 \\
\hline & $(0.246)$ & $(0.264)$ & $(6.399)^{*}$ & (5.891) & $(0.338)$ & $(0.641)^{* *}$ \\
\hline \multirow[t]{2}{*}{ listed } & 0.010 & 0.253 & 1.343 & -1.811 & -0.124 & -0.187 \\
\hline & $(0.133)$ & $(0.127)^{* *}$ & (3.685) & (2.692) & $(0.195)$ & (0.229) \\
\hline \multirow[t]{2}{*}{ jvd } & 0.106 & 0.068 & -13.505 & 1.562 & -0.216 & -0.357 \\
\hline & $(0.150)$ & $(0.137)$ & $(3.799)^{* * *}$ & (2.857) & $(0.192)$ & $(0.243)$ \\
\hline \multirow[t]{2}{*}{ jvf } & 0.295 & 0.352 & 1.532 & 1.591 & 0.714 & 0.184 \\
\hline & $(0.200)$ & $(0.172)^{* *}$ & (5.228) & (4.224) & $(0.307)^{* *}$ & $(0.470)$ \\
\hline \multirow[t]{2}{*}{ union } & 0.135 & 0.217 & -0.620 & 1.438 & 0.018 & 0.057 \\
\hline & $(0.122)$ & $(0.118)^{*}$ & (3.701) & (2.751) & $(0.184)$ & $(0.254)$ \\
\hline \multirow[t]{2}{*}{ Admin } & 0.002 & -0.004 & 0.060 & 0.036 & 0.024 & 0.013 \\
\hline & $(0.006)$ & $(0.005)$ & (0.139) & $(0.080)$ & $(0.007)^{* * *}$ & $(0.010)$ \\
\hline \multirow[t]{2}{*}{ Managers } & 0.019 & 0.005 & 0.146 & 0.069 & 0.009 & 0.003 \\
\hline & $(0.007)^{* * *}$ & $(0.007)$ & $(0.170)$ & $(0.108)$ & $(0.011)$ & $(0.014)$ \\
\hline \multirow[t]{2}{*}{ Other } & 0.011 & 0.009 & 0.199 & 0.165 & 0.012 & -0.008 \\
\hline & $(0.005)^{* *}$ & $(0.005)$ & $(0.160)$ & (0.103) & $(0.007)^{*}$ & (0.009) \\
\hline \multirow[t]{2}{*}{ Prod - US } & 0.002 & 0.004 & 0.134 & 0.060 & -0.000 & 0.001 \\
\hline & $(0.002)$ & $(0.002)^{*}$ & $(0.057)^{* *}$ & $(0.035)^{*}$ & $(0.003)$ & $(0.004)$ \\
\hline \multirow[t]{2}{*}{ Prod - Coll } & 0.002 & 0.006 & 0.062 & 0.261 & 0.005 & 0.003 \\
\hline & $(0.003)$ & $(0.002)^{* *}$ & $(0.068)$ & $(0.058) * * *$ & $(0.004)$ & $(0.005)$ \\
\hline \multirow[t]{2}{*}{ Adm - US } & -0.002 & 0.003 & 0.021 & 0.000 & 0.012 & 0.005 \\
\hline & $(0.005)$ & $(0.004)$ & $(0.114)$ & $(0.077)$ & $(0.006)^{*}$ & $(0.007)$ \\
\hline \multirow[t]{2}{*}{ Adm - Coll } & -0.003 & 0.001 & 0.110 & -0.036 & 0.001 & -0.000 \\
\hline & $(0.004)$ & $(0.003)$ & $(0.070)$ & $(0.055)$ & $(0.004)$ & $(0.006)$ \\
\hline \multirow[t]{2}{*}{ Age $<10$} & -0.315 & 0.152 & -5.353 & 0.272 & -0.265 & -0.211 \\
\hline & $(0.157)^{* *}$ & $(0.141)$ & $(4.122)$ & (2.647) & $(0.212)$ & $(0.255)$ \\
\hline \multirow[t]{2}{*}{ Age $11-20$} & -0.117 & -0.038 & -2.680 & -3.248 & -0.123 & 0.095 \\
\hline & $(0.124)$ & $(0.112)$ & (3.539) & (2.225) & $(0.165)$ & $(0.216)$ \\
\hline Observations & 454 & 454 & 454 & 454 & 422 & 418 \\
\hline R-squared & & & 0.28 & 0.29 & 0.22 & 0.15 \\
\hline
\end{tabular}


Table 5: Basic production functions in levels

\begin{tabular}{|c|c|c|c|}
\hline Panel A: Brazil & $(1)$ & $(2)$ & (3) \\
\hline Log employment & $\begin{array}{l}0.470 \\
(0.114)^{* * *}\end{array}$ & $\begin{array}{l}0.516 \\
(0.111)^{* * *}\end{array}$ & $\begin{array}{l}0.443 \\
(0.112)^{* * *}\end{array}$ \\
\hline Log materials & $\begin{array}{l}0.332 \\
(0.061)^{* * *}\end{array}$ & $\begin{array}{l}0.353 \\
(0.061)^{* * *}\end{array}$ & $\begin{array}{l}0.330 \\
(0.062)^{* * *}\end{array}$ \\
\hline Log GFA & $\begin{array}{l}0.227 \\
(0.082) * * *\end{array}$ & $\begin{array}{l}0.205 \\
(0.080)^{* *}\end{array}$ & $\begin{array}{l}0.203 \\
(0.079)^{* *}\end{array}$ \\
\hline Log ICT capital & $\begin{array}{l}0.157 \\
(0.047)^{* * *}\end{array}$ & & $\begin{array}{l}0.140 \\
(0.049)^{* * *}\end{array}$ \\
\hline Adoption=3 & & $\begin{array}{l}0.117 \\
(0.184)\end{array}$ & $\begin{array}{l}0.044 \\
(0.185)\end{array}$ \\
\hline Adoption=4 & & $\begin{array}{l}0.689 \\
(0.227)^{* * *}\end{array}$ & $\begin{array}{l}0.604 \\
(0.224)^{* * *}\end{array}$ \\
\hline Adoption=5 & & $\begin{array}{l}0.405 \\
(0.200)^{* *}\end{array}$ & $\begin{array}{l}0.267 \\
(0.210)\end{array}$ \\
\hline $\begin{array}{l}\text { Observations } \\
\text { R-squared }\end{array}$ & $\begin{array}{l}198 \\
0.83 \\
\end{array}$ & $\begin{array}{l}198 \\
0.83 \\
\end{array}$ & $\begin{array}{l}198 \\
0.84 \\
\end{array}$ \\
\hline Panel B: India & $(1)$ & $(2)$ & (3) \\
\hline Log employment & $\begin{array}{l}0.339 \\
(0.063)^{* * *}\end{array}$ & $\begin{array}{l}0.355 \\
(0.063)^{* * *}\end{array}$ & $\begin{array}{l}0.304 \\
(0.062)^{* * *}\end{array}$ \\
\hline Log materials & $\begin{array}{l}0.428 \\
(0.048) * * *\end{array}$ & $\begin{array}{l}0.436 \\
(0.046)^{* * *}\end{array}$ & $\begin{array}{l}0.423 \\
(0.047)^{* * *}\end{array}$ \\
\hline Log GFA & $\begin{array}{l}0.198 \\
(0.037)^{* * *}\end{array}$ & $\begin{array}{l}0.216 \\
(0.036)^{* * *}\end{array}$ & $\begin{array}{l}0.202 \\
(0.036)^{* * *}\end{array}$ \\
\hline Log ICT capital & $\begin{array}{l}0.115 \\
(0.032) * * *\end{array}$ & & $\begin{array}{l}0.101 \\
(0.032)^{* * *}\end{array}$ \\
\hline Adoption=3 & & $\begin{array}{l}0.365 \\
(0.107)^{* * *}\end{array}$ & $\begin{array}{l}0.326 \\
(0.108)^{* * *}\end{array}$ \\
\hline Adoption=4 & & $\begin{array}{l}0.568 \\
(0.136)^{* * *}\end{array}$ & $\begin{array}{l}0.534 \\
(0.134)^{* * *}\end{array}$ \\
\hline Adoption=5 & & $\begin{array}{l}0.253 \\
(0.149)^{*}\end{array}$ & $\begin{array}{l}0.227 \\
(0.149)\end{array}$ \\
\hline Observations & 335 & 335 & 335 \\
\hline R-squared & 0.87 & 0.87 & 0.88 \\
\hline
\end{tabular}


Table 6: Levels results controlling for omitted variables

\begin{tabular}{|c|c|c|c|c|}
\hline $\begin{array}{l}\text { Panel A: } \\
\text { Brazil }\end{array}$ & $\begin{array}{l}\text { (1) } \\
\text { baseline }\end{array}$ & $\begin{array}{l}\text { (2) } \\
\text { occupation }\end{array}$ & $\begin{array}{l}\text { (3) } \\
\text { occ \& skills }\end{array}$ & $\begin{array}{l}\text { (4) } \\
+ \text { other controls } \\
\end{array}$ \\
\hline Log employment & $\begin{array}{l}0.392 \\
(0.109)^{* * *}\end{array}$ & & & \\
\hline Log materials & $\begin{array}{l}0.359 \\
(0.062) * * *\end{array}$ & $\begin{array}{l}0.357 \\
(0.064) * * *\end{array}$ & $\begin{array}{l}0.369 \\
(0.064) * * *\end{array}$ & $\begin{array}{l}0.364 \\
(0.068) * * *\end{array}$ \\
\hline Log GFA & $\begin{array}{l}0.214 \\
(0.083) * *\end{array}$ & $\begin{array}{l}0.211 \\
(0.086) * *\end{array}$ & $\begin{array}{l}0.201 \\
(0.085)^{* *}\end{array}$ & $\begin{array}{l}0.209 \\
(0.087)^{* *}\end{array}$ \\
\hline Log ICT capital & $\begin{array}{l}0.173 \\
(0.042) * * *\end{array}$ & $\begin{array}{l}0.158 \\
(0.051)^{* * *}\end{array}$ & $\begin{array}{l}0.131 \\
(0.057)^{* *}\end{array}$ & $\begin{array}{l}0.120 \\
(0.066)^{*}\end{array}$ \\
\hline Production emp & & $\begin{array}{l}0.256 \\
(0.100)^{* *}\end{array}$ & & \\
\hline Admin emp & & $\begin{array}{l}0.157 \\
(0.140)\end{array}$ & & \\
\hline Managerial emp & & $\begin{array}{l}0.039 \\
(0.126)\end{array}$ & $\begin{array}{l}0.048 \\
(0.124)\end{array}$ & $\begin{array}{l}0.045 \\
(0.125)\end{array}$ \\
\hline Other emp & & $\begin{array}{l}0.041 \\
(0.072)\end{array}$ & $\begin{array}{l}0.024 \\
(0.067)\end{array}$ & $\begin{array}{l}0.019 \\
(0.063)\end{array}$ \\
\hline Skilled prod & & & $\begin{array}{l}0.102 \\
(0.074)\end{array}$ & $\begin{array}{l}0.113 \\
(0.082)\end{array}$ \\
\hline Unskilled prod & & & $\begin{array}{l}0.127 \\
(0.047)^{* * *}\end{array}$ & $\begin{array}{l}0.122 \\
(0.051)^{* *}\end{array}$ \\
\hline Skilled admin & & & $\begin{array}{l}0.175 \\
(0.085)^{* *}\end{array}$ & $\begin{array}{l}0.213 \\
(0.089) * *\end{array}$ \\
\hline Unskilled admin & & & $\begin{array}{l}0.111 \\
(0.078)\end{array}$ & $\begin{array}{l}0.076 \\
(0.095)\end{array}$ \\
\hline Observations & 172 & 172 & 172 & 172 \\
\hline R-squared & 0.84 & 0.84 & 0.84 & 0.85 \\
\hline
\end{tabular}




\begin{tabular}{|c|c|c|c|c|c|}
\hline Panel B: India & $\begin{array}{l}\text { (1) } \\
\text { baseline }\end{array}$ & $\begin{array}{l}\text { (2) } \\
\text { occupation }\end{array}$ & $\begin{array}{l}\text { (3) } \\
\text { occ \& skills }\end{array}$ & $\begin{array}{l}4) \\
+ \text { other controls }\end{array}$ & $\begin{array}{l}\text { (5) } \\
+ \text { software }\end{array}$ \\
\hline Log employment & $\begin{array}{l}0.337 \\
(0.066)^{* * *}\end{array}$ & & & & \\
\hline Log materials & $\begin{array}{l}0.434 \\
(0.051)^{* * *}\end{array}$ & $\begin{array}{l}0.452 \\
(0.049)^{* * *}\end{array}$ & $\begin{array}{l}0.444 \\
(0.049) * * *\end{array}$ & $\begin{array}{l}0.446 \\
(0.048)^{* * *}\end{array}$ & $\begin{array}{l}0.448 \\
(0.049)^{* * *}\end{array}$ \\
\hline Log GFA & $\begin{array}{l}0.188 \\
(0.038)^{* * *}\end{array}$ & $\begin{array}{l}0.205 \\
(0.040)^{* * *}\end{array}$ & $\begin{array}{l}0.213 \\
(0.039)^{* * *}\end{array}$ & $\begin{array}{l}0.209 \\
(0.041)^{* * *}\end{array}$ & $\begin{array}{l}0.205 \\
(0.041)^{* * *}\end{array}$ \\
\hline Log ICT capital & $\begin{array}{l}0.115 \\
(0.034) * * *\end{array}$ & $\begin{array}{l}0.082 \\
(0.034)^{* *}\end{array}$ & $\begin{array}{l}0.088 \\
(0.036)^{* *}\end{array}$ & $\begin{array}{l}0.095 \\
(0.037)^{* *}\end{array}$ & $\begin{array}{l}0.051 \\
(0.049)\end{array}$ \\
\hline Log software stock & & & & & $\begin{array}{l}0.073 \\
(0.047)\end{array}$ \\
\hline Production emp & & $\begin{array}{l}-0.019 \\
(0.070)\end{array}$ & & & \\
\hline Admin emp & & $\begin{array}{l}0.160 \\
(0.084)^{*}\end{array}$ & & & \\
\hline Managerial emp & & $\begin{array}{l}0.251 \\
(0.075)^{* * * *}\end{array}$ & $\begin{array}{l}0.267 \\
(0.073)^{* * *}\end{array}$ & $\begin{array}{l}0.240 \\
(0.074)^{* * *}\end{array}$ & $\begin{array}{l}0.231 \\
(0.073)^{* * *}\end{array}$ \\
\hline Other emp & & $\begin{array}{l}-0.032 \\
(0.044)\end{array}$ & $\begin{array}{l}-0.028 \\
(0.041)\end{array}$ & $\begin{array}{l}-0.039 \\
(0.043)\end{array}$ & $\begin{array}{l}-0.054 \\
(0.044)\end{array}$ \\
\hline Skilled prod & & & $\begin{array}{l}-0.026 \\
(0.051)\end{array}$ & $\begin{array}{l}-0.044 \\
(0.055)\end{array}$ & $\begin{array}{l}-0.043 \\
(0.056)\end{array}$ \\
\hline Unskilled prod & & & $\begin{array}{l}0.014 \\
(0.036)\end{array}$ & $\begin{array}{l}-0.000 \\
(0.040)\end{array}$ & $\begin{array}{l}0.003 \\
(0.040)\end{array}$ \\
\hline Skilled admin & & & $\begin{array}{l}0.113 \\
(0.080)\end{array}$ & $\begin{array}{l}0.137 \\
(0.085)\end{array}$ & $\begin{array}{l}0.127 \\
(0.086)\end{array}$ \\
\hline Unskilled admin & & & $\begin{array}{l}0.067 \\
(0.059)\end{array}$ & $\begin{array}{l}0.064 \\
(0.062)\end{array}$ & $\begin{array}{l}0.062 \\
(0.061)\end{array}$ \\
\hline Observations & 312 & 312 & 312 & 312 & 312 \\
\hline R-squared & 0.87 & 0.87 & 0.87 & 0.87 & 0.88 \\
\hline
\end{tabular}


Table 7: Two-year differences (2001-2003)

\begin{tabular}{|c|c|c|c|c|c|}
\hline Panel A: Brazil & $\begin{array}{l}1) \\
\text { Levels }\end{array}$ & $\begin{array}{l}\text { (2) } \\
\text { Baseline }\end{array}$ & $\begin{array}{l}\text { (3) } \\
\text { Occupation }\end{array}$ & $\begin{array}{l}\text { (4) } \\
\text { Occ\&skills }\end{array}$ & $\begin{array}{l}\text { (5) } \\
\text { Other controls }\end{array}$ \\
\hline Log employment & $\begin{array}{l}0.262 \\
(0.139)^{*}\end{array}$ & $\begin{array}{l}0.190 \\
(0.096) * *\end{array}$ & & & \\
\hline Log materials & $\begin{array}{l}0.534 \\
(0.111)^{* * *}\end{array}$ & $\begin{array}{l}0.369 \\
(0.124) * * *\end{array}$ & $\begin{array}{l}0.364 \\
(0.132)^{* * *}\end{array}$ & $\begin{array}{l}0.349 \\
(0.122)^{* * *}\end{array}$ & $\begin{array}{l}0.296 \\
(0.127)^{* *}\end{array}$ \\
\hline Log GFA & $\begin{array}{l}0.190 \\
(0.115)\end{array}$ & $\begin{array}{l}0.159 \\
(0.132)\end{array}$ & $\begin{array}{l}0.167 \\
(0.130)\end{array}$ & $\begin{array}{l}0.199 \\
(0.135)\end{array}$ & $\begin{array}{l}0.132 \\
(0.145)\end{array}$ \\
\hline Log ICT capital & $\begin{array}{l}0.123 \\
(0.081)\end{array}$ & $\begin{array}{l}0.193 \\
(0.070)^{* * *}\end{array}$ & $\begin{array}{l}0.217 \\
(0.069) * * *\end{array}$ & $\begin{array}{l}0.195 \\
(0.060) * * *\end{array}$ & $\begin{array}{l}0.223 \\
(0.063) * * *\end{array}$ \\
\hline Production emp & & & $\begin{array}{l}-0.062 \\
(0.137)\end{array}$ & & \\
\hline Admin emp & & & $\begin{array}{l}0.306 \\
(0.137)^{* *}\end{array}$ & & \\
\hline Managerial emp & & & $\begin{array}{l}-0.076 \\
(0.088)\end{array}$ & $\begin{array}{l}-0.061 \\
(0.087)\end{array}$ & $\begin{array}{l}-0.084 \\
(0.096)\end{array}$ \\
\hline Other emp & & & $\begin{array}{l}0.023 \\
(0.051)\end{array}$ & $\begin{array}{l}0.016 \\
(0.058)\end{array}$ & $\begin{array}{l}0.020 \\
(0.061)\end{array}$ \\
\hline Skilled prod & & & & $\begin{array}{l}0.160 \\
(0.186)\end{array}$ & $\begin{array}{l}0.162 \\
(0.191)\end{array}$ \\
\hline Unskilled prod & & & & $\begin{array}{l}0.042 \\
(0.094)\end{array}$ & $\begin{array}{l}0.003 \\
(0.094)\end{array}$ \\
\hline Skilled admin & & & & $\begin{array}{l}0.001 \\
(0.146)\end{array}$ & $\begin{array}{l}0.039 \\
(0.148)\end{array}$ \\
\hline Unskilled admin & & & & $\begin{array}{l}0.059 \\
(0.077)\end{array}$ & $\begin{array}{l}0.055 \\
(0.111)\end{array}$ \\
\hline Observations & 130 & 130 & 130 & 130 & 130 \\
\hline R-squared & 0.78 & 0.59 & 0.60 & 0.60 & 0.66 \\
\hline
\end{tabular}




\begin{tabular}{|c|c|c|c|c|c|c|}
\hline Panel B: India & $\begin{array}{l}(1) \\
\text { Levels }\end{array}$ & $\begin{array}{l}(2) \\
\text { Baseline }\end{array}$ & $\begin{array}{l}\text { (3) } \\
\text { Occupation }\end{array}$ & $\begin{array}{l}\text { (4) } \\
\text { Occ\&skills }\end{array}$ & $\begin{array}{l}\text { (5) } \\
\text { Other controls }\end{array}$ & $\begin{array}{l}\text { (6) } \\
\text { Software }\end{array}$ \\
\hline Log employment & $\begin{array}{l}0.081 \\
(0.139)\end{array}$ & $\begin{array}{l}0.180 \\
(0.078)^{* *}\end{array}$ & & & & \\
\hline Log materials & $\begin{array}{l}0.563 \\
(0.074)^{* * *}\end{array}$ & $\begin{array}{l}0.343 \\
(0.104) * * *\end{array}$ & $\begin{array}{l}0.364 \\
(0.108) * * *\end{array}$ & $\begin{array}{l}0.358 \\
(0.107)^{* * *}\end{array}$ & $\begin{array}{l}0.335 \\
(0.109) * * *\end{array}$ & $\begin{array}{l}0.346 \\
(0.105) * * *\end{array}$ \\
\hline Log GFA & $\begin{array}{l}0.099 \\
(0.061)\end{array}$ & $\begin{array}{l}0.154 \\
(0.099)\end{array}$ & $\begin{array}{l}0.154 \\
(0.101)\end{array}$ & $\begin{array}{l}0.149 \\
(0.098)\end{array}$ & $\begin{array}{l}0.128 \\
(0.094)\end{array}$ & $\begin{array}{l}0.175 \\
(0.095)^{*}\end{array}$ \\
\hline Log ICT capital & $\begin{array}{l}0.175 \\
(0.063)^{* * *}\end{array}$ & $\begin{array}{l}0.101 \\
(0.039)^{* *}\end{array}$ & $\begin{array}{l}0.095 \\
(0.039)^{* *}\end{array}$ & $\begin{array}{l}0.084 \\
(0.040)^{* *}\end{array}$ & $\begin{array}{l}0.101 \\
(0.044)^{* *}\end{array}$ & $\begin{array}{l}0.091 \\
(0.037)^{* *}\end{array}$ \\
\hline Log software & & & & & & $\begin{array}{l}0.036 \\
(0.038)\end{array}$ \\
\hline Production emp & & & $\begin{array}{l}-0.013 \\
(0.039)\end{array}$ & & & \\
\hline Admin emp & & & $\begin{array}{l}0.059 \\
(0.051)\end{array}$ & & & \\
\hline Managerial emp & & & $\begin{array}{l}0.005 \\
(0.049)\end{array}$ & $\begin{array}{l}0.021 \\
(0.048)\end{array}$ & $\begin{array}{l}0.025 \\
(0.054)\end{array}$ & $\begin{array}{l}0.025 \\
(0.054)\end{array}$ \\
\hline Other emp & & & $\begin{array}{l}0.099 \\
(0.055)^{*}\end{array}$ & $\begin{array}{l}0.121 \\
(0.052)^{* *}\end{array}$ & $\begin{array}{l}0.120 \\
(0.053)^{* *}\end{array}$ & $\begin{array}{l}0.101 \\
(0.059)^{*}\end{array}$ \\
\hline Skilled prod & & & & $\begin{array}{l}0.012 \\
(0.040)\end{array}$ & $\begin{array}{l}0.013 \\
(0.040)\end{array}$ & $\begin{array}{l}0.009 \\
(0.039)\end{array}$ \\
\hline Unskilled prod & & & & $\begin{array}{l}-0.037 \\
(0.037)\end{array}$ & $\begin{array}{l}-0.042 \\
(0.036)\end{array}$ & $\begin{array}{l}-0.049 \\
(0.039)\end{array}$ \\
\hline Skilled admin & & & & $\begin{array}{l}0.055 \\
(0.046)\end{array}$ & $\begin{array}{l}0.053 \\
(0.048)\end{array}$ & $\begin{array}{l}0.063 \\
(0.046)\end{array}$ \\
\hline Unskilled admin & & & & $\begin{array}{l}-0.053 \\
(0.038)\end{array}$ & $\begin{array}{l}-0.047 \\
(0.043)\end{array}$ & $\begin{array}{l}-0.061 \\
(0.041)\end{array}$ \\
\hline Observations & 248 & 248 & 248 & 248 & 248 & 248 \\
\hline R-squared & 0.68 & 0.38 & 0.39 & 0.40 & 0.43 & 0.46 \\
\hline
\end{tabular}


Table 8: Organisational change: flattening

\begin{tabular}{|c|c|c|c|c|}
\hline Panel A: Brazil & $\begin{array}{l}(1) \\
\text { Full }\end{array}$ & $\begin{array}{l}(2) \\
\text { Full }\end{array}$ & $\begin{array}{l}(3) \\
3-5\end{array}$ & $\begin{array}{l}(4) \\
3-5\end{array}$ \\
\hline Log employment & $\begin{array}{l}0.180 \\
(0.087) * *\end{array}$ & $\begin{array}{l}0.167 \\
(0.086) *\end{array}$ & $\begin{array}{l}0.295 \\
(0.125)^{* *}\end{array}$ & $\begin{array}{l}0.271 \\
(0.102) * *\end{array}$ \\
\hline Log materials & $\begin{array}{l}0.367 \\
(0.121)^{* * *}\end{array}$ & $\begin{array}{l}0.351 \\
(0.115)^{* * *}\end{array}$ & $\begin{array}{l}0.407 \\
(0.158)^{* *}\end{array}$ & $\begin{array}{l}0.394 \\
(0.160)^{* *}\end{array}$ \\
\hline Log GFA & $\begin{array}{l}0.111 \\
(0.122)\end{array}$ & $\begin{array}{l}0.099 \\
(0.116)\end{array}$ & $\begin{array}{l}0.029 \\
(0.173)\end{array}$ & $\begin{array}{l}0.010 \\
(0.162)\end{array}$ \\
\hline Log ICT capital & $\begin{array}{l}0.160 \\
(0.065)^{* *}\end{array}$ & $\begin{array}{l}0.100 \\
(0.058) *\end{array}$ & $\begin{array}{l}0.087 \\
(0.079)\end{array}$ & $\begin{array}{l}0.025 \\
(0.074)\end{array}$ \\
\hline Org change & $\begin{array}{l}-0.005 \\
(0.046)\end{array}$ & $\begin{array}{l}-0.169 \\
(0.095)^{*}\end{array}$ & $\begin{array}{l}-0.003 \\
(0.061)\end{array}$ & $\begin{array}{l}-0.373 \\
(0.172)^{* *}\end{array}$ \\
\hline OC * ICT capital & & $\begin{array}{l}0.150 \\
(0.091)\end{array}$ & & $\begin{array}{l}0.296 \\
(0.125)^{* *}\end{array}$ \\
\hline Observations & 156 & 156 & 105 & 105 \\
\hline R-squared & 0.55 & 0.56 & 0.62 & 0.65 \\
\hline \multicolumn{5}{|l|}{ Panel B: India } \\
\hline & $\begin{array}{l}(1) \\
\text { Full } \\
\end{array}$ & $\begin{array}{l}(2) \\
\text { Full } \\
\end{array}$ & $\begin{array}{l}(3) \\
3-5 \\
\end{array}$ & $\begin{array}{l}(4) \\
3-5\end{array}$ \\
\hline Log employment & $\begin{array}{l}0.159 \\
(0.069) * *\end{array}$ & $\begin{array}{l}0.160 \\
(0.070)^{* *}\end{array}$ & $\begin{array}{l}0.136 \\
(0.086)\end{array}$ & $\begin{array}{l}0.137 \\
(0.086)\end{array}$ \\
\hline Log materials & $\begin{array}{l}0.355 \\
(0.103)^{* * *}\end{array}$ & $\begin{array}{l}0.357 \\
(0.103)^{* * * *}\end{array}$ & $\begin{array}{l}0.273 \\
(0.115)^{* *}\end{array}$ & $\begin{array}{l}0.276 \\
(0.114)^{* *}\end{array}$ \\
\hline Log GFA & $\begin{array}{l}0.155 \\
(0.095)\end{array}$ & $\begin{array}{l}0.154 \\
(0.095)\end{array}$ & $\begin{array}{l}0.170 \\
(0.118)\end{array}$ & $\begin{array}{l}0.170 \\
(0.118)\end{array}$ \\
\hline Log ICT capital & $\begin{array}{l}0.088 \\
(0.038)^{* *}\end{array}$ & $\begin{array}{l}0.093 \\
(0.039) * *\end{array}$ & $\begin{array}{l}0.069 \\
(0.037)^{*}\end{array}$ & $\begin{array}{l}0.084 \\
(0.038)^{* *}\end{array}$ \\
\hline Org change & $\begin{array}{l}0.020 \\
(0.020)\end{array}$ & $\begin{array}{l}0.032 \\
(0.055)\end{array}$ & $\begin{array}{l}0.045 \\
(0.020)^{* *}\end{array}$ & $\begin{array}{l}0.080 \\
(0.066)\end{array}$ \\
\hline OC * ICT capital & & $\begin{array}{l}-0.011 \\
(0.042)\end{array}$ & & $\begin{array}{l}-0.030 \\
(0.049)\end{array}$ \\
\hline Observations & 266 & 266 & 158 & 158 \\
\hline R-squared & 0.38 & 0.38 & 0.51 & 0.51 \\
\hline
\end{tabular}


Table 9: Organisational change: improved monitoring

\begin{tabular}{|c|c|c|c|c|}
\hline \multicolumn{5}{|l|}{ Panel A: Brazil } \\
\hline & (1) & (2) & (3) & (4) \\
\hline & Full & Full & $3-5$ & $3-5$ \\
\hline \multirow[t]{2}{*}{ Log employment } & 0.180 & 0.181 & 0.295 & 0.287 \\
\hline & $(0.087)^{* *}$ & $(0.088)^{* *}$ & $(0.124)^{* *}$ & $(0.118)^{* *}$ \\
\hline \multirow{2}{*}{ Log materials } & 0.367 & 0.364 & 0.407 & 0.418 \\
\hline & $(0.120)^{* * *}$ & $(0.120)^{* * *}$ & $(0.162)^{* *}$ & $(0.162)^{* *}$ \\
\hline \multirow[t]{2}{*}{ Log GFA } & 0.111 & 0.092 & 0.030 & -0.004 \\
\hline & $(0.122)$ & $(0.119)$ & $(0.164)$ & $(0.151)$ \\
\hline \multirow[t]{2}{*}{ Log ICT capital } & 0.160 & 0.127 & 0.087 & -0.017 \\
\hline & $(0.066)^{* *}$ & $(0.071)^{*}$ & $(0.086)$ & $(0.108)$ \\
\hline \multirow[t]{2}{*}{ Org change } & 0.002 & -0.022 & 0.000 & -0.078 \\
\hline & $(0.024)$ & $(0.035)$ & $(0.035)$ & $(0.064)$ \\
\hline \multirow[t]{2}{*}{ OC * ICT capital } & & 0.023 & & 0.068 \\
\hline & & $(0.034)$ & & $(0.055)$ \\
\hline Observations & 156 & 156 & 105 & 105 \\
\hline R-squared & 0.55 & 0.55 & 0.62 & 0.63 \\
\hline \multicolumn{5}{|l|}{ Panel B: India } \\
\hline & (1) & (2) & (3) & (4) \\
\hline & Full & Full & $3-5$ & $3-5$ \\
\hline \multirow[t]{2}{*}{ Log employment } & 0.156 & 0.155 & 0.130 & 0.130 \\
\hline & $(0.069)^{* *}$ & $(0.070)^{* *}$ & $(0.088)$ & $(0.089)$ \\
\hline \multirow[t]{2}{*}{ Log materials } & 0.352 & 0.350 & 0.271 & 0.272 \\
\hline & $(0.105)^{* * *}$ & $(0.105)^{* * *}$ & $(0.118)^{* *}$ & $(0.117)^{* *}$ \\
\hline \multirow[t]{2}{*}{ Log GFA } & 0.157 & 0.157 & 0.184 & 0.184 \\
\hline & $(0.095)^{*}$ & $(0.095)^{*}$ & $(0.121)$ & $(0.121)$ \\
\hline \multirow[t]{2}{*}{ Log ICT capital } & 0.093 & 0.088 & 0.076 & 0.083 \\
\hline & $(0.039)^{* *}$ & $(0.040)^{* *}$ & $(0.038)^{* *}$ & $(0.042)^{* *}$ \\
\hline \multirow[t]{2}{*}{ Org change } & 0.018 & 0.010 & 0.025 & 0.034 \\
\hline & $(0.015)$ & $(0.026)$ & $(0.018)$ & $(0.043)$ \\
\hline \multirow{2}{*}{ OC * ICT capital } & & 0.008 & & -0.009 \\
\hline & & $(0.020)$ & & $(0.035)$ \\
\hline Observations & 266 & 266 & 158 & 158 \\
\hline R-squared & 0.38 & 0.38 & 0.50 & 0.50 \\
\hline
\end{tabular}


Table 10: Organisational change: improved management decision making

\begin{tabular}{|c|c|c|c|c|}
\hline Panel A: Brazil & $\begin{array}{l}\text { (1) } \\
\text { Full }\end{array}$ & $\begin{array}{l}(2) \\
\text { Full }\end{array}$ & $\begin{array}{l}(3) \\
3-5 \\
\end{array}$ & $\begin{array}{l}(4) \\
3-5 \\
\end{array}$ \\
\hline Log employment & $\begin{array}{l}0.179 \\
(0.088)^{* *}\end{array}$ & $\begin{array}{l}0.182 \\
(0.088)^{* *}\end{array}$ & $\begin{array}{l}0.297 \\
(0.125)^{* *}\end{array}$ & $\begin{array}{l}0.292 \\
(0.127)^{* *}\end{array}$ \\
\hline Log materials & $\begin{array}{l}0.361 \\
(0.121)^{* * *}\end{array}$ & $\begin{array}{l}0.357 \\
(0.118)^{* * *}\end{array}$ & $\begin{array}{l}0.408 \\
(0.157)^{* *}\end{array}$ & $\begin{array}{l}0.418 \\
(0.162)^{* *}\end{array}$ \\
\hline Log GFA & $\begin{array}{l}0.113 \\
(0.121)\end{array}$ & $\begin{array}{l}0.124 \\
(0.118)\end{array}$ & $\begin{array}{l}0.028 \\
(0.164)\end{array}$ & $\begin{array}{l}0.020 \\
(0.154)\end{array}$ \\
\hline Log ICT capital & $\begin{array}{l}0.157 \\
(0.067)^{* *}\end{array}$ & $\begin{array}{l}0.223 \\
(0.123)^{*}\end{array}$ & $\begin{array}{l}0.085 \\
(0.082)\end{array}$ & $\begin{array}{l}0.056 \\
(0.149)\end{array}$ \\
\hline Org change & $\begin{array}{l}-0.050 \\
(0.056)\end{array}$ & $\begin{array}{l}0.051 \\
(0.116)\end{array}$ & $\begin{array}{l}-0.024 \\
(0.087)\end{array}$ & $\begin{array}{l}-0.073 \\
(0.202)\end{array}$ \\
\hline OC * ICT capital & & $\begin{array}{l}-0.097 \\
(0.113)\end{array}$ & & $\begin{array}{l}0.043 \\
(0.155)\end{array}$ \\
\hline $\begin{array}{l}\text { Observations } \\
\text { R-squared }\end{array}$ & $\begin{array}{l}156 \\
0.55\end{array}$ & $\begin{array}{l}156 \\
0.55\end{array}$ & $\begin{array}{l}105 \\
0.62\end{array}$ & $\begin{array}{l}105 \\
0.62\end{array}$ \\
\hline Panel B: India & $\begin{array}{l}\text { (1) } \\
\text { Full }\end{array}$ & $\begin{array}{l}\text { (2) } \\
\text { Full }\end{array}$ & $\begin{array}{l}(3) \\
3-5 \\
\end{array}$ & $\begin{array}{l}(4) \\
3-5 \\
\end{array}$ \\
\hline Log employment & $\begin{array}{l}0.171 \\
(0.070) * *\end{array}$ & $\begin{array}{l}0.170 \\
(0.070)^{* *}\end{array}$ & $\begin{array}{l}0.150 \\
(0.090)^{*}\end{array}$ & $\begin{array}{l}0.149 \\
(0.091)\end{array}$ \\
\hline Log materials & $\begin{array}{l}0.353 \\
(0.103)^{* * *}\end{array}$ & $\begin{array}{l}0.352 \\
(0.103)^{* * *}\end{array}$ & $\begin{array}{l}0.271 \\
(0.116)^{* *}\end{array}$ & $\begin{array}{l}0.270 \\
(0.116)^{* *}\end{array}$ \\
\hline Log GFA & $\begin{array}{l}0.149 \\
(0.095)\end{array}$ & $\begin{array}{l}0.149 \\
(0.095)\end{array}$ & $\begin{array}{l}0.167 \\
(0.119)\end{array}$ & $\begin{array}{l}0.167 \\
(0.120)\end{array}$ \\
\hline Log ICT capital & $\begin{array}{l}0.089 \\
(0.038)^{* *}\end{array}$ & $\begin{array}{l}0.085 \\
(0.045)^{*}\end{array}$ & $\begin{array}{l}0.071 \\
(0.040)^{*}\end{array}$ & $\begin{array}{l}0.065 \\
(0.046)\end{array}$ \\
\hline Org change & $\begin{array}{l}0.063 \\
(0.030)^{* *}\end{array}$ & $\begin{array}{l}0.051 \\
(0.067)\end{array}$ & $\begin{array}{l}0.090 \\
(0.035)^{* *}\end{array}$ & $\begin{array}{l}0.072 \\
(0.088)\end{array}$ \\
\hline OC * ICT capital & & $\begin{array}{l}0.011 \\
(0.057)\end{array}$ & & $\begin{array}{l}0.017 \\
(0.071)\end{array}$ \\
\hline Observations & 266 & 266 & 158 & 158 \\
\hline R-squared & 0.38 & 0.38 & 0.51 & 0.51 \\
\hline
\end{tabular}


Table 11: Descriptive statistics on regional averages of constraints

\begin{tabular}{lcccccc}
\hline & \multicolumn{3}{c}{ Brazil } & & \multicolumn{3}{c}{ India } \\
& Mean & Median & s.d & Mean & Median & s.d \\
\hline Power disruptions & & & & & & \\
$\quad$ Mean days disrupted & - & - & - & 21.76 & 16.71 & 7.86 \\
Median days disrupted & - & - & - & 9.09 & 2.00 & 11.35 \\
Reported constraints & & & & & & \\
Availability of skills & 0.54 & 0.50 & 0.13 & 0.44 & 0.30 & 0.23 \\
Unions & 0.20 & 0.21 & 0.09 & 0.14 & 0.08 & 0.16 \\
Labour regulations & 0.40 & 0.37 & 0.10 & 0.30 & 0.18 & 0.27 \\
Internet availability / price & 0.45 & 0.40 & 0.08 & 0.49 & 0.40 & 0.28 \\
$\quad$ Low internet usage & 0.47 & 0.41 & 0.11 & 0.51 & 0.44 & 0.16 \\
Lack of government support & 0.52 & 0.56 & 0.10 & 0.39 & 0.28 & 0.25 \\
& & & & & &
\end{tabular}

Notes: reported constraints variables are the proportion of firms in each region/state reporting that the relevant constraint has prevented them from investing in ICT to their preferred level; availability of skills is an average across four types of workers; standard deviations are for the variation in the mean values across 7 Brazilian regions and 9 Indian States.

Table 12: Power disruptions and ICT adoption across Indian states

\begin{tabular}{|c|c|c|c|c|c|}
\hline Panel A: Levels & $\begin{array}{l}\text { (1) } \\
\text { Adoption }\end{array}$ & $\begin{array}{l}\text { (2) } \\
\text { Usage }\end{array}$ & $\begin{array}{l}\text { (3) } \\
\text { \%usingPCs }\end{array}$ & $\begin{array}{l}(4) \\
\text { \%usingMch }\end{array}$ & $\begin{array}{l}(5) \\
\ln (\mathrm{ict} / \mathrm{y})\end{array}$ \\
\hline Mean days disrupted & $\begin{array}{l}-0.025 \\
(0.010)^{* * *}\end{array}$ & $\begin{array}{l}-0.001 \\
(0.009)\end{array}$ & $\begin{array}{l}-0.415 \\
(0.368)\end{array}$ & $\begin{array}{l}-0.073 \\
(0.257)\end{array}$ & $\begin{array}{l}-0.051 \\
(0.019)^{* *}\end{array}$ \\
\hline $\begin{array}{l}\text { Observations } \\
\text { R-squared }\end{array}$ & 454 & 454 & $\begin{array}{l}454 \\
0.20\end{array}$ & $\begin{array}{l}454 \\
0.25\end{array}$ & $\begin{array}{l}418 \\
0.09\end{array}$ \\
\hline
\end{tabular}

\begin{tabular}{|c|c|c|c|c|c|}
\hline Panel B: Changes & $\begin{array}{l}\text { (1) } \\
\text { dAdoption }\end{array}$ & $\begin{array}{l}\text { (2) } \\
\text { dUsage }\end{array}$ & $\begin{array}{l}\text { (3) } \\
\text { d\%usingPCs }\end{array}$ & $\begin{array}{l}\text { (4) } \\
\text { d\%usingMch }\end{array}$ & $\begin{array}{l}\text { (5) } \\
\text { dln(ict/y) }\end{array}$ \\
\hline Mean days disrupted & $\begin{array}{l}-0.022 \\
(0.010)^{* *}\end{array}$ & $\begin{array}{l}0.002 \\
(0.005)\end{array}$ & $\begin{array}{l}-0.164 \\
(0.061)^{* *}\end{array}$ & $\begin{array}{l}-0.213 \\
(0.129)\end{array}$ & $\begin{array}{l}0.011 \\
(0.007)\end{array}$ \\
\hline $\begin{array}{l}\text { Observations } \\
\text { R-squared }\end{array}$ & 452 & 452 & $\begin{array}{l}452 \\
0.15\end{array}$ & $\begin{array}{l}452 \\
0.15\end{array}$ & $\begin{array}{l}417 \\
0.21\end{array}$ \\
\hline
\end{tabular}


Table 13: Power disruptions and returns to ICT across Indian states

\begin{tabular}{lll}
\hline & $(1)$ & $(2)$ \\
\hline & & \\
Log employment & 0.148 & 0.158 \\
Log materials & $(0.038)^{* * *}$ & $(0.040)^{* * *}$ \\
& 0.359 & 0.358 \\
Log GFA & $(0.117)^{* *}$ & $(0.114)^{* *}$ \\
& 0.153 & 0.155 \\
Log ICT capital & $(0.098)$ & $(0.094)$ \\
& 0.246 & 0.122 \\
Mean days * ICT & $(0.049)^{* * *}$ & $(0.046)^{* *}$ \\
& -0.008 & \\
Median days * ICT & $(0.002)^{* * *}$ & -0.005 \\
& & $(0.002)^{* *}$ \\
Observations & & \\
R-squared & 266 & 266 \\
\hline
\end{tabular}

Figure 4: Power disruptions and elasticity of ICT capital across Indian states

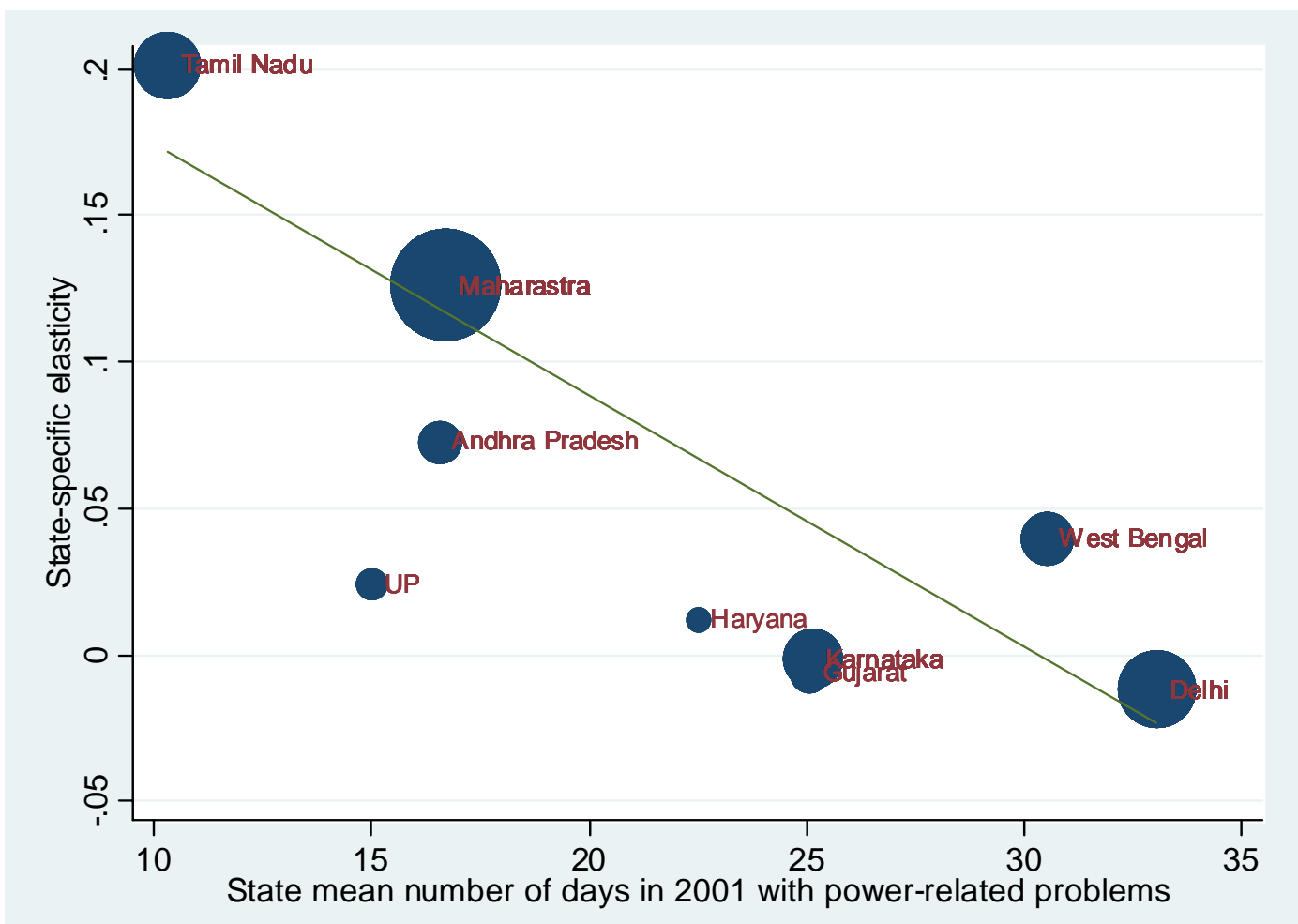


Table 14: Constraints and returns to ICT capital across Indian states

\begin{tabular}{|c|c|c|c|c|c|c|}
\hline & $(1)$ & (2) & (3) & (4) & (5) & (6) \\
\hline Log employment & $\begin{array}{l}0.158 \\
(0.040) * * *\end{array}$ & $\begin{array}{l}0.160 \\
(0.040)^{* * *}\end{array}$ & $\begin{array}{l}0.159 \\
(0.040)^{* * *}\end{array}$ & $\begin{array}{l}0.162 \\
(0.040) * * *\end{array}$ & $\begin{array}{l}0.161 \\
(0.040) * * *\end{array}$ & $\begin{array}{l}0.159 \\
(0.040) * * *\end{array}$ \\
\hline Log materials & $\begin{array}{l}0.360 \\
(0.116)^{* *}\end{array}$ & $\begin{array}{l}0.358 \\
(0.115) * *\end{array}$ & $\begin{array}{l}0.358 \\
(0.115)^{* *}\end{array}$ & $\begin{array}{l}0.358 \\
(0.115)^{* *}\end{array}$ & $\begin{array}{l}0.359 \\
(0.115) * *\end{array}$ & $\begin{array}{l}0.357 \\
(0.114)^{* *}\end{array}$ \\
\hline Log GFA & $\begin{array}{l}0.154 \\
(0.095)\end{array}$ & $\begin{array}{l}0.154 \\
(0.094)\end{array}$ & $\begin{array}{l}0.153 \\
(0.094)\end{array}$ & $\begin{array}{l}0.153 \\
(0.094)\end{array}$ & $\begin{array}{l}0.153 \\
(0.094)\end{array}$ & $\begin{array}{l}0.153 \\
(0.094)\end{array}$ \\
\hline Log ICT capital & $\begin{array}{l}0.169 \\
(0.059)^{* *}\end{array}$ & $\begin{array}{l}0.108 \\
(0.044)^{* *}\end{array}$ & $\begin{array}{l}0.131 \\
(0.051)^{* *}\end{array}$ & $\begin{array}{l}0.145 \\
(0.067)^{*}\end{array}$ & $\begin{array}{l}0.237 \\
(0.095)^{* *}\end{array}$ & $\begin{array}{l}0.158 \\
(0.062)^{* *}\end{array}$ \\
\hline Skills * ICT & $\begin{array}{l}-0.210 \\
(0.070)^{* *}\end{array}$ & & & & & \\
\hline Unions * ICT & & $\begin{array}{l}-0.172 \\
(0.121)\end{array}$ & & & & \\
\hline Lab laws * ICT & & & $\begin{array}{l}-0.174 \\
(0.085)^{*}\end{array}$ & & & \\
\hline i-access * ICT & & & & $\begin{array}{l}-0.136 \\
(0.089)\end{array}$ & & \\
\hline i-users * ICT & & & & & $\begin{array}{l}-0.319 \\
(0.137)^{* *}\end{array}$ & \\
\hline Gov * ICT & & & & & & $\begin{array}{l}-0.197 \\
(0.097)^{*}\end{array}$ \\
\hline Observations & 266 & 266 & 266 & 266 & 266 & 266 \\
\hline R-squared & 0.38 & 0.38 & 0.38 & 0.38 & 0.38 & 0.38 \\
\hline
\end{tabular}

Table 15: Constraints and returns to ICT capital across Brazilian regions

\begin{tabular}{|c|c|c|c|c|c|c|}
\hline & $(1)$ & $(2)$ & (3) & (4) & (5) & (6) \\
\hline Log employment & $\begin{array}{l}0.186 \\
(0.142)\end{array}$ & $\begin{array}{l}0.202 \\
(0.126)\end{array}$ & $\begin{array}{l}0.198 \\
(0.129)\end{array}$ & $\begin{array}{l}0.179 \\
(0.138)\end{array}$ & $\begin{array}{l}0.192 \\
(0.128)\end{array}$ & $\begin{array}{l}0.180 \\
(0.141)\end{array}$ \\
\hline Log materials & $\begin{array}{l}0.365 \\
(0.107)^{* *}\end{array}$ & $\begin{array}{l}0.368 \\
(0.105)^{* *}\end{array}$ & $\begin{array}{l}0.372 \\
(0.099) * * *\end{array}$ & $\begin{array}{l}0.376 \\
(0.104)^{* *}\end{array}$ & $\begin{array}{l}0.380 \\
(0.106)^{* *}\end{array}$ & $\begin{array}{l}0.367 \\
(0.105)^{* *}\end{array}$ \\
\hline Log GFA & $\begin{array}{l}0.113 \\
(0.107)\end{array}$ & $\begin{array}{l}0.115 \\
(0.114)\end{array}$ & $\begin{array}{l}0.119 \\
(0.115)\end{array}$ & $\begin{array}{l}0.110 \\
(0.108)\end{array}$ & $\begin{array}{l}0.116 \\
(0.115)\end{array}$ & $\begin{array}{l}0.112 \\
(0.107)\end{array}$ \\
\hline Log ICT capital & $\begin{array}{l}0.306 \\
(0.224)\end{array}$ & $\begin{array}{l}0.372 \\
(0.092) * * *\end{array}$ & $\begin{array}{l}0.707 \\
(0.287)^{* *}\end{array}$ & $\begin{array}{l}0.433 \\
(0.368)\end{array}$ & $\begin{array}{l}0.672 \\
(0.313) *\end{array}$ & $\begin{array}{l}0.194 \\
(0.200)\end{array}$ \\
\hline Skills * ICT & $\begin{array}{l}-0.286 \\
(0.480)\end{array}$ & & & & & \\
\hline Unions * ICT & & $\begin{array}{l}-1.176 \\
(0.580)^{*}\end{array}$ & & & & \\
\hline Lab laws * ICT & & & $\begin{array}{l}-1.454 \\
(0.838)\end{array}$ & & & \\
\hline i-access * ICT & & & & $\begin{array}{l}-0.634 \\
(0.911)\end{array}$ & & \\
\hline i-users * ICT & & & & & $\begin{array}{l}-1.164 \\
(0.753)\end{array}$ & \\
\hline Gov * ICT & & & & & & $\begin{array}{l}-0.069 \\
(0.407)\end{array}$ \\
\hline Observations & 156 & 156 & 156 & 156 & 156 & 156 \\
\hline R-squared & 0.55 & 0.55 & 0.56 & 0.55 & 0.55 & 0.55 \\
\hline
\end{tabular}


Figure 5: Union constraint and elasticity of ICT capital across Brazilian regions (excluding Centro)

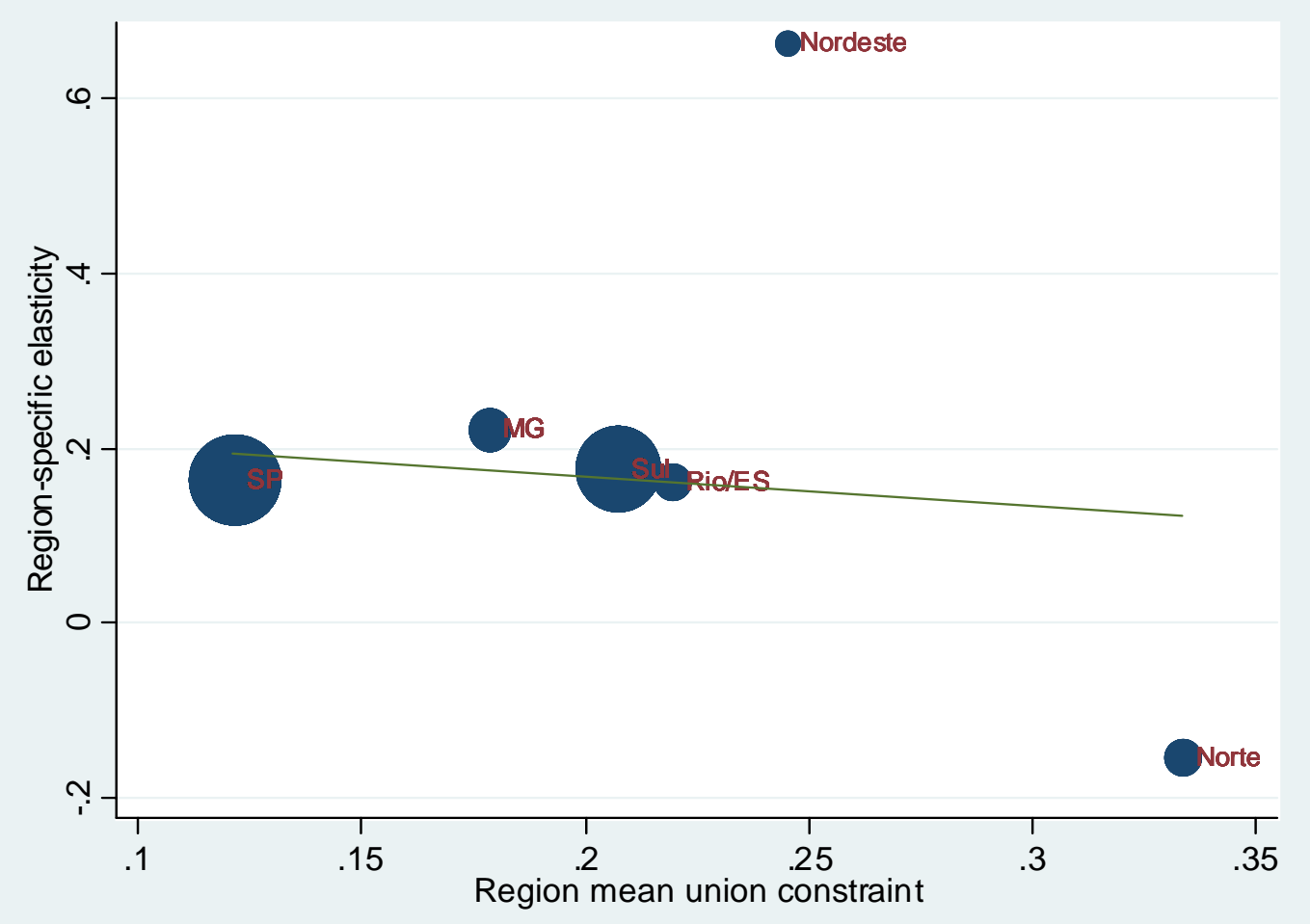




\section{Appendix A}

Table A1: Sample distribution by region/state and sector

\begin{tabular}{|c|c|c|c|c|c|c|c|}
\hline & $\begin{array}{c}\text { Electronic } \\
\text { Components }\end{array}$ & $\begin{array}{c}\text { Plastic } \\
\text { Products }\end{array}$ & $\begin{array}{c}\text { Soap \& } \\
\text { Detergents }\end{array}$ & $\begin{array}{l}\text { Auto } \\
\text { Parts }\end{array}$ & $\begin{array}{c}\text { Machine } \\
\text { Tools }\end{array}$ & $\begin{array}{l}\text { Wearing } \\
\text { Apparel }\end{array}$ & Total \\
\hline \multicolumn{8}{|l|}{ Panel A: Brazil } \\
\hline Norte & 2 & 4 & 2 & 1 & 0 & 3 & 12 \\
\hline Nordeste & 1 & 12 & 9 & 1 & 7 & 19 & 49 \\
\hline Sul & 18 & 26 & 9 & 24 & 33 & 25 & 135 \\
\hline Centro & 2 & 6 & 8 & 3 & 3 & 4 & 26 \\
\hline Rio / Espirito Santo & 4 & 8 & 6 & 6 & 7 & 10 & 41 \\
\hline Sao Paulo & 29 & 20 & 31 & 37 & 23 & 33 & 173 \\
\hline Minais Gerais & 20 & 5 & 12 & 6 & 8 & 5 & 56 \\
\hline Total & 76 & 81 & 77 & 78 & 81 & 99 & 492 \\
\hline \multicolumn{8}{|l|}{ Panel B: India } \\
\hline Andhra Pradesh & 8 & 10 & 1 & 4 & 4 & 0 & 27 \\
\hline Delhi & 14 & 22 & 10 & 27 & 5 & 23 & 101 \\
\hline Gujarat & 2 & 15 & 2 & 1 & 1 & 4 & 25 \\
\hline Haryana & 0 & 0 & 0 & 6 & 0 & 0 & 6 \\
\hline Karnataka & 12 & 4 & 1 & 8 & 10 & 3 & 38 \\
\hline Maharashtra & 25 & 56 & 22 & 32 & 17 & 22 & 174 \\
\hline Tamil Nadu & 10 & 8 & 2 & 18 & 9 & 7 & 54 \\
\hline Uttar Pradesh & 3 & 1 & 1 & 5 & 0 & 0 & 10 \\
\hline West Bengal & 4 & 10 & 8 & 9 & 6 & 4 & 41 \\
\hline Total & 78 & 126 & 47 & 110 & 52 & 63 & 476 \\
\hline
\end{tabular}

Table A2: Branch information for Brazil and India

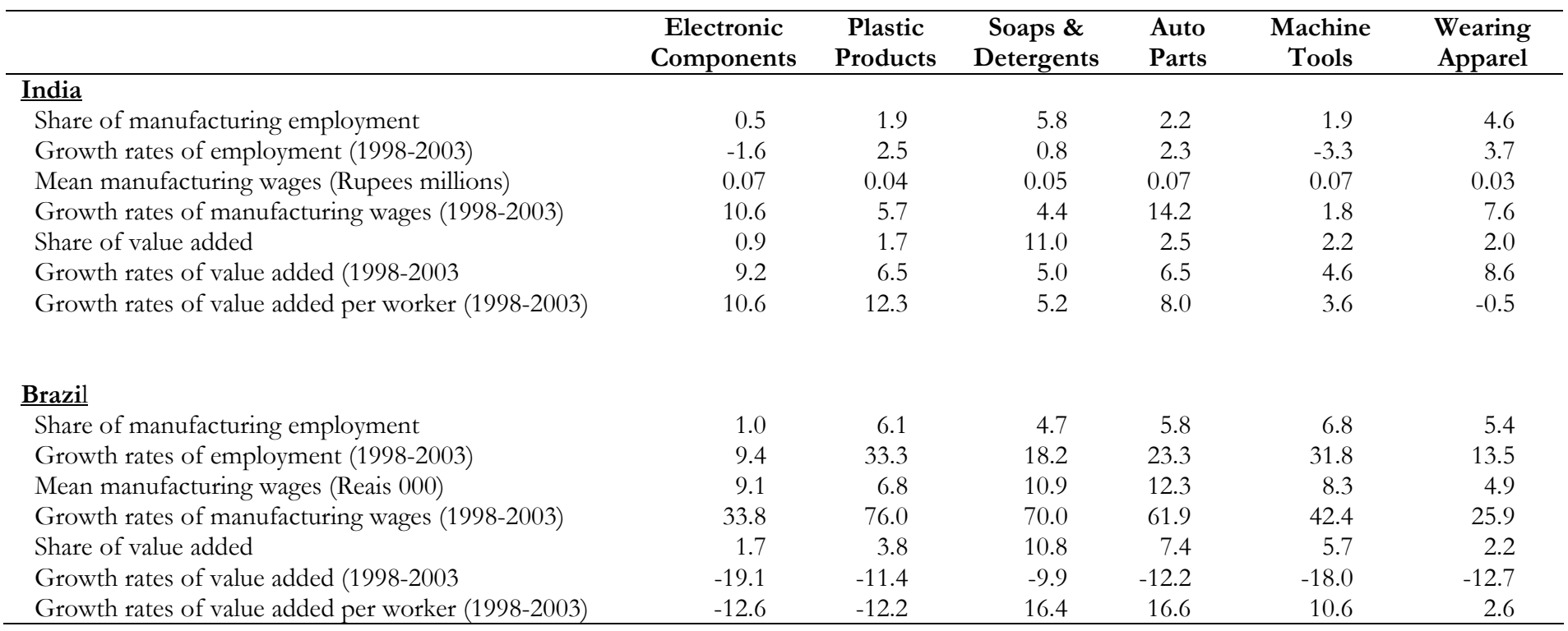


Table A3: Country indicators for ICT, 2000 and 2004

\begin{tabular}{lcccc}
\hline & \multicolumn{3}{c}{ Brazil } & \multicolumn{2}{c}{ India } \\
& $\mathbf{2 0 0 0}$ & $\mathbf{2 0 0 4}$ & $\mathbf{2 0 0 0}$ & $\mathbf{2 0 0 4}$ \\
\hline GNI per capita (current US\$) & 3590 & 3090 & 450 & 620 \\
Adult literacy rate (\%) & n.a & 89 & n.a & 61 \\
Tertiary enrolment rate & 16 & 22 & 10 & 11 \\
ICT expenditure/GDP & 5.6 & 6.7 & 3.6 & 3.7 \\
Secure Internet servers (per 1m) & 6.0 & 11.2 & 0.1 & 0.4 \\
Telephone main lines (per1000) & 182 & 237 & 32 & 43 \\
Internet users (per 1000) & 29 & 109 & 5 & 23 \\
PCs (per 1000) & 50 & 86 & 5 & 11 \\
Broadband subscribers (per 1000) & 0.6 & 12.8 & 0 & 0.6 \\
International Internet bandwidth (bits per person) & 5 & 154 & 1 & 4 \\
\hline
\end{tabular}

Source: World Bank, 2006

Table A4: Comparing means for in-sample and out-of sample firms

\begin{tabular}{lcccccc}
\hline & \multicolumn{3}{c}{ Brazil } & & \multicolumn{3}{c}{ India } \\
& In & Out & p-value & In & Out & p-value \\
\hline $\begin{array}{l}\text { ICT adoption } \\
\quad\end{array}$ & & & & & \\
$\quad$ ICT adoption index & 3.43 & 3.54 & 0.315 & 2.96 & 2.90 & 0.586 \\
ICT usage index & 11.49 & 11.75 & 0.408 & 10.87 & 10.31 & $0.096^{*}$ \\
\% using PCs & 76.23 & 64.96 & $0.001^{* * *}$ & 57.12 & 46.29 & $0.002^{* * *}$ \\
\% using ICT machinery & 21.07 & 24.89 & 0.192 & 15.76 & 14.21 & 0.508 \\
Other measures & & & & & & \\
$\quad$ Employees & 184.1 & 231.9 & 0.277 & 312.8 & 496.2 & $0.089^{*}$ \\
Age & 23.9 & 23.2 & 0.660 & 20.6 & 24.1 & $0.010^{* *}$ \\
Union membership & 49.2 & 43.8 & 0.186 & 12.6 & 13.8 & 0.657 \\
\% admin and clerical & 17.5 & 20.7 & $0.009 * * *$ & 21.3 & 21.4 & 0.914 \\
\% college educated & 34.5 & 33.9 & 0.829 & 77.5 & 75.9 & 0.608 \\
& & & & & & \\
\hline
\end{tabular}

Notes: values for Brazil are comparing 198 firms in the basic production function sample with other firms in the sample; for India the comparison is 335 firms in the basic sample and other firms. 
Table A5: Descriptive statistics for production functions in levels

\begin{tabular}{|c|c|c|c|c|c|c|c|c|}
\hline & \multicolumn{4}{|c|}{ Brazil } & \multicolumn{4}{|c|}{ India } \\
\hline & Mean & Median & s.d & \multicolumn{2}{|c|}{ Obs } & Median & s.d & Obs. \\
\hline Log sales & 15.27 & 15.16 & 2.12 & 198 & 18.21 & 18.06 & 2.03 & 335 \\
\hline Log employment & 4.21 & 4.08 & 1.43 & \multicolumn{2}{|c|}{198} & 4.24 & 1.53 & 335 \\
\hline Log materials & 13.97 & 13.71 & 2.14 & \multicolumn{2}{|c|}{159} & 16.81 & 2.16 & 335 \\
\hline Log GFA & 14.32 & 14.15 & 2.17 & \multicolumn{2}{|l|}{136} & 16.52 & 2.10 & 335 \\
\hline Log ICT capital & 10.43 & 10.41 & 1.94 & 198 & 12.57 & 12.62 & 2.09 & 335 \\
\hline \multicolumn{9}{|c|}{ Table A6: Basic production functions and imputation } \\
\hline & \multirow{2}{*}{\multicolumn{2}{|c|}{$\begin{array}{l}\text { (1) } \\
\text { B, drop }\end{array}$}} & (2) & \multirow{2}{*}{\multicolumn{2}{|c|}{$\begin{array}{l}\text { (3) } \\
\text { B, only dum }\end{array}$}} & (4) & \multirow{2}{*}{\multicolumn{2}{|c|}{$\begin{array}{l}\text { (5) } \\
\text { I, only dum }\end{array}$}} \\
\hline & & & B, real+dum & & & I, drop & & \\
\hline Log employment & \multicolumn{2}{|c|}{$\begin{array}{l}0.370 \\
(0.121)^{* * * *}\end{array}$} & $\begin{array}{l}0.470 \\
(0.114) * * *\end{array}$ & \multicolumn{2}{|r|}{$\begin{array}{l}0.479 \\
(0.123)^{* * *}\end{array}$} & $\begin{array}{l}0.339 \\
(0.063)^{* * *}\end{array}$ & \multicolumn{2}{|c|}{$\begin{array}{l}0.354 \\
(0.069)^{* * *}\end{array}$} \\
\hline Log materials & \multicolumn{2}{|c|}{$\begin{array}{l}0.314 \\
(0.071)^{* * *}\end{array}$} & $\begin{array}{l}0.332 \\
(0.061)^{* * *}\end{array}$ & & & $\begin{array}{l}0.428 \\
(0.048)^{* * *}\end{array}$ & & \\
\hline Log GFA & \multicolumn{2}{|c|}{$\begin{array}{l}0.303 \\
(0.081)^{* * *}\end{array}$} & $\begin{array}{l}0.227 \\
(0.082)^{* * *}\end{array}$ & & & $\begin{array}{l}0.198 \\
(0.037)^{* * *}\end{array}$ & & \\
\hline Log ICT capital & \multicolumn{2}{|c|}{$\begin{array}{l}0.124 \\
(0.052)^{* *}\end{array}$} & $\begin{array}{l}0.157 \\
(0.047)^{* * *}\end{array}$ & \multicolumn{2}{|r|}{$\begin{array}{l}0.165 \\
(0.058)^{* * *}\end{array}$} & $\begin{array}{l}0.115 \\
(0.032)^{* * *}\end{array}$ & \multicolumn{2}{|c|}{$\begin{array}{l}0.121 \\
(0.035) * * *\end{array}$} \\
\hline Observations & \multicolumn{2}{|c|}{132} & 198 & \multirow{2}{*}{\multicolumn{2}{|c|}{$\begin{array}{l}198 \\
0.78\end{array}$}} & 335 & \multicolumn{2}{|c|}{335} \\
\hline R-squared & \multicolumn{2}{|c|}{0.85} & 0.83 & & & 0.87 & \multicolumn{2}{|c|}{0.86} \\
\hline
\end{tabular}

Table A7: Sensitivity of returns to ICT

\begin{tabular}{|c|c|c|c|c|c|c|}
\hline & $\begin{array}{l}(1) \\
\text { B,all }\end{array}$ & $\begin{array}{l}\text { (2) } \\
\text { B,drop 1-2 }\end{array}$ & $\begin{array}{l}\text { (3) } \\
\text { B, drop olrs }\end{array}$ & $\begin{array}{l}\text { (4) } \\
\text { I,all }\end{array}$ & $\begin{array}{l}\text { (5) } \\
\text { I,drop 1-2 }\end{array}$ & $\begin{array}{l}\text { (6) } \\
\text { I,drop olrs }\end{array}$ \\
\hline Log employment & $\begin{array}{l}0.470 \\
(0.114) * * *\end{array}$ & $\begin{array}{l}0.468 \\
(0.170) * * *\end{array}$ & $\begin{array}{l}0.553 \\
(0.083) * * *\end{array}$ & $\begin{array}{l}0.339 \\
(0.063) * * *\end{array}$ & $\begin{array}{l}0.331 \\
(0.077) * * *\end{array}$ & $\begin{array}{l}0.365 \\
(0.051)^{* * *}\end{array}$ \\
\hline Log materials & $\begin{array}{l}0.332 \\
(0.061)^{* * *}\end{array}$ & $\begin{array}{l}0.303 \\
(0.078) * * *\end{array}$ & $\begin{array}{l}0.302 \\
(0.054) * * *\end{array}$ & $\begin{array}{l}0.428 \\
(0.048)^{* * *}\end{array}$ & $\begin{array}{l}0.422 \\
(0.054) * * *\end{array}$ & $\begin{array}{l}0.320 \\
(0.046)^{* * *}\end{array}$ \\
\hline Log GFA & $\begin{array}{l}0.227 \\
(0.082)^{* * *}\end{array}$ & $\begin{array}{l}0.288 \\
(0.108)^{* * *}\end{array}$ & $\begin{array}{l}0.108 \\
(0.065)^{*}\end{array}$ & $\begin{array}{l}0.198 \\
(0.037)^{* * *}\end{array}$ & $\begin{array}{l}0.203 \\
(0.048) * * *\end{array}$ & $\begin{array}{l}0.130 \\
(0.029)^{* * *}\end{array}$ \\
\hline Log ICT capital & $\begin{array}{l}0.157 \\
(0.047)^{* * *}\end{array}$ & $\begin{array}{l}0.108 \\
(0.059)^{*}\end{array}$ & $\begin{array}{l}0.191 \\
(0.045)^{* * *}\end{array}$ & $\begin{array}{l}0.115 \\
(0.032)^{* * *}\end{array}$ & $\begin{array}{l}0.086 \\
(0.042)^{* *}\end{array}$ & $\begin{array}{l}0.276 \\
(0.038)^{* * *}\end{array}$ \\
\hline $\begin{array}{l}\text { Observations } \\
\text { R-squared }\end{array}$ & $\begin{array}{l}198 \\
0.83\end{array}$ & $\begin{array}{l}133 \\
0.81\end{array}$ & $\begin{array}{l}159 \\
0.89\end{array}$ & $\begin{array}{l}335 \\
0.87\end{array}$ & $\begin{array}{l}199 \\
0.87\end{array}$ & $\begin{array}{l}268 \\
0.91\end{array}$ \\
\hline
\end{tabular}


Table A8: Descriptive statistics for production functions in differences

\begin{tabular}{|c|c|c|c|c|c|c|c|c|}
\hline & \multicolumn{4}{|c|}{ Brazil } & \multicolumn{4}{|c|}{ India } \\
\hline & Mean & Median & s.d & Obs & Mean & Median & s.d & Obs. \\
\hline DLog sales & 0.252 & 0.201 & 0.372 & 156 & 0.250 & 0.223 & 0.277 & 266 \\
\hline DLog Demployment & 0.092 & 0.042 & 0.361 & 156 & 0.145 & 0.134 & 0.253 & 266 \\
\hline DLog materials & 0.310 & 0.288 & 0.403 & 129 & 0.269 & 0.223 & 0.312 & 266 \\
\hline DLog GFA & 0.209 & 0.182 & 0.291 & 104 & 0.157 & 0.091 & 0.224 & 266 \\
\hline DLog ICT capital & 1.071 & 0.998 & 0.562 & 156 & 1.016 & 1.025 & 0.500 & 266 \\
\hline
\end{tabular}

Table A9: Two year difference results: outliers and imputation

\begin{tabular}{|c|c|c|c|c|c|}
\hline & $\begin{array}{l}(1) \\
\text { B,all }\end{array}$ & $\begin{array}{l}(2) \\
\text { B,out }\end{array}$ & $\begin{array}{l}\text { (3) } \\
\text { B,out,imp }\end{array}$ & $\begin{array}{l}\text { (4) } \\
\text { I,all }\end{array}$ & $\begin{array}{l}\text { (5) } \\
\text { I,out }\end{array}$ \\
\hline Log employment & $\begin{array}{l}0.317 \\
(0.215)\end{array}$ & $\begin{array}{l}0.185 \\
(0.103)^{*}\end{array}$ & $\begin{array}{l}0.180 \\
(0.087) * *\end{array}$ & $\begin{array}{l}0.644 \\
(0.297)^{* *}\end{array}$ & $\begin{array}{l}0.162 \\
(0.070)^{* *}\end{array}$ \\
\hline Log materials & $\begin{array}{l}0.165 \\
(0.110)\end{array}$ & $\begin{array}{l}0.394 \\
(0.146)^{* * *}\end{array}$ & $\begin{array}{l}0.367 \\
(0.120) * * *\end{array}$ & $\begin{array}{l}0.157 \\
(0.069) * *\end{array}$ & $\begin{array}{l}0.358 \\
(0.103)^{* * *}\end{array}$ \\
\hline Log GFA & $\begin{array}{l}-0.078 \\
(0.164)\end{array}$ & $\begin{array}{l}0.147 \\
(0.120)\end{array}$ & $\begin{array}{l}0.112 \\
(0.122)\end{array}$ & $\begin{array}{l}-0.065 \\
(0.116)\end{array}$ & $\begin{array}{l}0.157 \\
(0.095)^{*}\end{array}$ \\
\hline Log ICT capital & $\begin{array}{l}0.116 \\
(0.086)\end{array}$ & $\begin{array}{l}0.138 \\
(0.075)^{*}\end{array}$ & $\begin{array}{l}0.160 \\
(0.065)^{* *}\end{array}$ & $\begin{array}{l}0.152 \\
(0.077) * *\end{array}$ & $\begin{array}{l}0.084 \\
(0.037)^{* *}\end{array}$ \\
\hline Observations & 134 & 103 & 156 & 356 & 266 \\
\hline R-squared & 0.19 & 0.44 & 0.55 & 0.07 & 0.37 \\
\hline
\end{tabular}


Table A10: Correlations between power disruptions and constraints across states

\begin{tabular}{lllllll}
\hline & $\begin{array}{l}\text { Days } \\
\text { disrupted }\end{array}$ & Skills & Unions & $\begin{array}{l}\text { Labour } \\
\text { laws }\end{array}$ & $\begin{array}{l}\text { Internet } \\
\text { avail. or } \\
\text { price }\end{array}$ & $\begin{array}{l}\text { No. using } \\
\text { the net }\end{array}$ \\
\hline Days of disruptions & 1.0000 & & & & & \\
Skills & 0.6383 & 1.0000 & & & & \\
Unions & 0.3853 & 0.8593 & 1.0000 & & & \\
Labour laws & 0.6116 & 0.9527 & 0.9336 & 1.0000 & & \\
Internet avail or price & 0.5539 & 0.9380 & 0.9055 & 0.9825 & 1.0000 & \\
No. using the net & 0.6791 & 0.9478 & 0.7913 & 0.9476 & 0.9653 & 1.0000 \\
Lack of gov support & 0.6226 & 0.9101 & 0.9332 & 0.9839 & 0.9569 & 0.9188 \\
& & & & & & \\
\hline
\end{tabular}

